kuLTura - meDia- TeoLogia

ISSN 2081-8971

$2017 \mathrm{nr} 28$, s. 109-139.

\title{
Zagraniczne podróże apostolskie papieża Franciszka w najważniejszych krajowych portalach internetowych (lata 2013-2014)
}

Foreign apostolic journeys of Pope Francis on the most important national news websites (2013-2014)

\begin{abstract}
STRESZCZENIE:
KoŚCIÓŁ, W SWOJEJ DZIAŁALNOŚCI, POSŁUGIWAŁ SIE I POSŁUGUJE MEDIAMI. NA POCZĄTKU CZASOPISMAMI, RADIEM, TELEWIZJA, AŻ W KOŃCU INTERNETEM. TO OSTATNIE MEDIUM DOŚĆ SKUTECZNIE WYPIERA TE WCZEŚNIEJSZE I STAJE SIĘ MIEJSCEM KOMUNIKOWANIA MYŚLI. W PODJĘTYCH BADANIACH PODDANO ANALIZIE WIODĄCE PORTALE OPINIOTWÓRCZE W POLSCE (WWW.ONET.PL, WWW.WP.PL, WWW.INTERIA.PL, WWW.GAZETA.PL, WWW.O2.PL I WWW.FAKT.PL), W KONTEKŚCIE PUBLIKOWANIA TEKSTÓW DOTYCZĄCYCH PIERWSZYCH SZEŚCIU ZAGRANICZNYCH PODRÓŻY APOSTOLSKICH PAPIEŻA FRANCISZKa. ZBADANO ILOŚĆ, JAKOŚĆ, RODZAJ, CZAS I CZĘTOTLIWOŚĆ PUBLIKACJI, A TAKŻE WYCIĄGNIĘTO WNIOSKI PASTORALNE.
\end{abstract}

\section{SŁOWA KLUCZOWE:}

PODRÓŻE APOSTOLSKIE, PIELGRZYMKI PAPIEŻA, PAPIEŻ

FRANCISZEK, MEDIA, INTERNET, PORTALE OPINIOTWÓRCZE

\begin{abstract}
:
The CATHOLIC CHURCh, IN ITS ACTIVITY, HAS BEEN USING MEDIA. AT FIRST MAGAZINES, RADIO, TELEVISION AND FINALLY THE INTERNET. THE LAST MEDIUM MENTIONED HAS BEEN QUITE SUCCESSFULLY DISPLACING THE PREVIOUS ONES AND IS BECOMING A PLATFORM TO COMMUNICATE IDEAS AND THOUGHTS. IN THE UNDERTAKEN RESEARCH SOME LEADING POLISH NEWS WEBSITES WERE ANALYSED (WWW.ONET.PL, WWW.WP.PL, WWW.INTERIA.PL, WWW.GAZETA.PL, WWW.O2.PL AND WWW.FAKT.PL) IN THE ASPECT OF PUBLISHING NEWS COVERAGE OF THE FIRST SIX FOREIGN APOSTOLIC JOURNEYS OF POPE FRANCIS. NUMBER, QUALITY, TYPE, PERIOD AND TIME OF PUBLICATIONS WERE EXAMINED. PASTORAL CONCLUSIONS WERE ALSO DRAWN.
\end{abstract}

\section{KEYWORDS:}

APOSTOLIC JOURNEYS, THE POPE'S PILGRIMAGES, POPE FRANCIS, THE MEDIA, THE INTERNET, INFLUENTIAL NEWS WEBSITES 
$\mathrm{J}$ orge Mario Bergoglio SJ (ur. 17 grudnia 1936 r. w Buenos Aires) - argentyński duchowny rzymskokatolicki, w latach 1998-2013 arcybiskup Buenos Aires i tym samym prymas Argentyny, w latach 2001-2013 kardynał, 13 marca 2013 r. został 266. papieżem. Od samego początku pontyfikatu budził zainteresowanie światowych i polskich środków społecznego przekazu.

Internet powoli wypiera papier, radio i telewizję, dlatego to on stał się miejscem publikacji dotyczących papieża. To w tej przestrzeni aktualnie dokonuje się największy przepływ informacji, idei i myśli. Najpopularniejszymi serwisami informacyjno-publicystycznymi w Polsce są: www.onet.pl, www.wp.pl, www.interia.pl, www.gazeta.pl, www.o2.pl i www.fakt.pl. Warto zauważyć, że największą grupę użytkowników posiada portal www.onet.pl, który osiąga czytelnictwo na poziomie 12,5 mln użytkowników miesięcznie, co przedkłada się na prawie $60 \%$ użytkowników Internetu w Polsce, a najmniejszą portal www.fakt.pl, odpowiednio 4,4 mln. czytelników, czyli $20 \%$ użytkowników ${ }^{1}$. Te portale mają zatem ogromną rolę opiniotwórczą, kształtująca postawy swoich użytkowników, tym bardziej że udział w rynku portali chrześcijańskich i katolickich jest niewielki²

Kościół zauważa konieczność obecności w tej przestrzeni. Nowe technologie informacyjne są wielopłaszczyznowe. Stanowią dla Kościoła nie tylko nowe narzędzia służące do wypełniania jego misji ewangelizacyjnej, ale są przestrzenią, w której Kościół powinien być obecny i którą powinien przepajać wartościami Ewangelii. Teologowie środków społecznego przekazu zauważają, że o ile do niedawna „Kościół prowadził misje i przenosił ziarno Ewangelii z kontynentu na kontynent, o tyle na przełomie XX i XXI

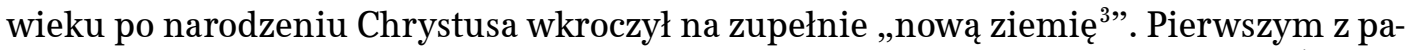
pieży, który zauważył szczególną rolę Internetu, był Jan Paweł II. W orędziu na Światowy Dzień Środków Społecznego Przekazu mówił o „erze komputerów” i wykorzystywaniu „skomputeryzowanych systemów uczestnictwa”, czyli Internetu, do realizacji misji Kościoła ${ }^{4}$. Papież Benedykt XVI nazywa Internet „,cyfrowym kontynentem, który powinien być ewangelizowany, ale też ewangelizuje ${ }^{5}$, a papież Franciszek ukazuje media internetowe jako praktyczne narzędzia, które mogą uczestniczyć w komunikowaniu miło-

$1 \quad$ Zob. http://www.media2.pl/badania/132461-Polski-internet-w-lutym.-Top-20-domen.html (dostęp 5.04.2016 r.). Jest to specjalistyczny portal, na którym publikowane są badania dotyczące użytkowania Internetu. Wg tych badań do portali opiniotwórczych które uzyskują czytelnictwo na poziomie min. ok. 5 mln. userów w Polsce należą: www.onet.pl (12,5 mln. użytkowników, 60\% zasięgu w Internecie), www.wp.pl (10,5 mln, 47,7\%), www.interia.pl (7,5 mln, 34,4\%), www.gazeta.pl (6,5 mln, 26,8\%), www.o2.pl (5,2 mln, 23,7\%) i www.fakt.pl (4,4 mln, 20,2\%). Źródło: Megapanel PBI/Gemius, luty 2016, liczebność próby: $\mathrm{N}=100$ 883, grupa objęta badaniem 7-75 lat.

2 Zob.http://www.wirtualnemedia.pl/artykul/ponad-2-mln-polskich-uzytkownikow-serwisow-religijnych-na-czele-deon-i-opoka-top-10 (dostęp 5.04.2016 r.). Według tych badań najczęściej odwiedzanymi chrześcijańskimi witrynami były: www.deon.pl (0,5 mln., 2,3\%), www.opoka.org.pl (0,49 mln., 2,3\%) i www.adonai.pl (0,3 mln., 1,2\%). Źródło: Megapanel PBI/Gemius, maj 2014, liczebność próby: N=10 000, grupa objęta badaniem 7-75 lat.

3 J. Kloch, Kościół w Polsce wobec Web 2.0, Kielce 2013, s. 21.

4 Zob. Jan Paweł II, Misja Kościoła w erze komputerów. Orędzie na 24. Światowy Dzień Środków Społecznego Przekazu, 24 stycznia $1990 \mathrm{r}$. 

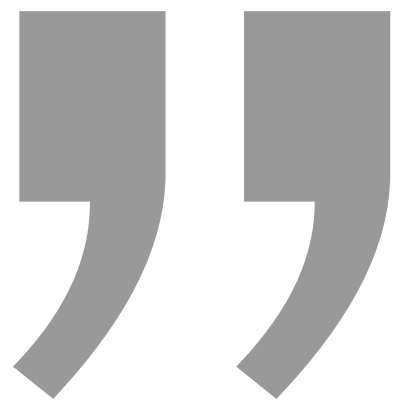

\section{Kościół zauważa konieczność}

obecności w tej przestrzeni.

Nowe technologie informacyjne są

wielopłaszczyznowe. Stanowia dla Kościoła

nie tylko nowe narzędzia służące do wypełniania

jego misji ewangelizacyjnej,

ale są przestrzenią,

w której Kościół powinien być obecny

i którą powinien przepajać wartościami Ewangelii.

sierdzia $^{6}$. O ile chrześcijańskie portale internetowe szeroko informują o działalności eklezjalnej i analizują ją, o tyle nie podjęto jeszcze szerszych badań dotyczących jego obecności w strefie świeckiej Internetu.

Niniejsze badanie będzie dotyczyło niewielkiego wycinka tej obecności w najczęściej odwiedzanych portalach opiniotwórczych w kraju. Będzie wiązało się z papieżem Franciszkiem i jego pielgrzymkami apostolskimi (lata 2013-2014), czyli tematem działalności misyjnej Kościoła, bardzo dobrze odbieranym i - jak się wydaje - budzącym zainteresowanie mediów świeckich. Proces badawczy będzie miał dwa etapy: pierwszym będzie przetwarzania artykułów zamieszczonych w Internecie metodą ilościowo-jakościowej analizy treści. Następnie dokonamy analizy teologiczno-misjologicznej otrzymanych danych i wyciagniemy wnioski pastoralne. Prace badawcze podzielimy zatem na:

- analizę treści artykułów dotyczących pielgrzymek misyjnych papieża Franciszka (2013-2014) w najważniejszych portalach w kraju metodą ilościowo-jakościową. Zebrane artykuły dotyczą następujących pielgrzymek:

1. 22-29 lipca 2013 r. - Brazylia;

2. 24-26 maja 2014 r. - Jordania, Palestyna, Izrael (Ziemia Święta);

3. 14-18 sierpnia 2014 r. - Korea Południowa;

4. 21 września 2014 r. - Albania;

5. 25 listopada 2014 r. - Francja;

6. 28-30 listopada 2014 r. - Turcja.

- analizę teologiczną opublikowanych tekstów;

- wnioski pastoralne.

5 Zob. Benedykt XVI, Nowe technologie, nowe relacje. Trzeba rozpowszechniać kulturę szacunku, dialogu i przyjaźni. Orędzie na 43. Światowy Dzień Środków Społecznego Przekazu, 24 stycznia 2009 r.

6 Zob. Franciszek, Komunikacja i Miłosierdzie - owocne spotkanie. Orędzie na 50. Światowy Dzień Środków Społecznego Przekazu, 24 stycznia 2016 r. 


\section{Analiza artykułów dotyczących pielgrzymek misyjnych papieża Franciszka (2013-2014) zamieszczonych w najważniejszych portalach w kraju metodą ilościowo-jakościową}

\begin{tabular}{|c|c|}
\hline \multicolumn{2}{|c|}{ Metodologia pierwszego etapu prowadzenia badania } \\
\hline $\begin{array}{l}\text { 1. Analizowany } \\
\text { okres: }\end{array}$ & $\begin{array}{l}\text { a. } 22 \text { kwietnia } 2013 \text { r. - } 29 \text { października } 2013 \text { r.; } \\
\text { b. } 24 \text { lutego } 2014 \text { r. - } 26 \text { sierpnia } 2014 \text { r.; } \\
\text { c. } 14 \text { maja } 2014 \text { r. - } 18 \text { listopada } 2014 \text { r.; } \\
\text { d. } 21 \text { czerwca } 2014 \text { r. - } 21 \text { grudnia } 2014 \text { r.; } \\
\text { e. } 25 \text { sierpnia } 2014 \text { r. - } 25 \text { lutego } 2015 \text { r.; } \\
\text { f. } 28 \text { sierpnia } 2014 \text { r. - } 28 \text { lutego } 2015 \text { r; } \\
\text { Trzy miesiące przed i trzy miesiące po pielgrzymkach papieskich, } \\
\text { w latach 2013-2014 (ten czas wystarczy, aby przeanalizować zarówno } \\
\text { zapowiedzi, jak i podsumowania wizyt apostolskich papieża) }\end{array}$ \\
\hline $\begin{array}{l}\text { 2. Analizowane ser- } \\
\text { wisy: }\end{array}$ & $\begin{array}{l}\text { www.onet.pl; www.wp.pl; www.interia.pl; www.gazeta.pl; www.o2.pl } \\
\text { i www.fakt.pl (portale opiniotwórcze uzyskujące czytelnictwo na } \\
\text { poziomie min. ok. } 5 \text { mln. użytkowników w Polsce) }\end{array}$ \\
\hline 3. Źródła treści: & Newspoint $^{7}$ \\
\hline $\begin{array}{l}\text { 4. Glębokość anali- } \\
\text { zy: }\end{array}$ & łączona (automatyczna i ręczna) \\
\hline 5. Język źródeł: & polski \\
\hline $\begin{array}{l}\text { 6. Język wyszukiwa- } \\
\text { nia: }\end{array}$ & polski \\
\hline $\begin{array}{l}\text { 7. Filtrowanie spa- } \\
\text { mu/bootów: }\end{array}$ & łączone (automatycznie i ręcznie) \\
\hline $\begin{array}{l}\text { 8. Zapytanie/słowa } \\
\text { kluczowe: }\end{array}$ & 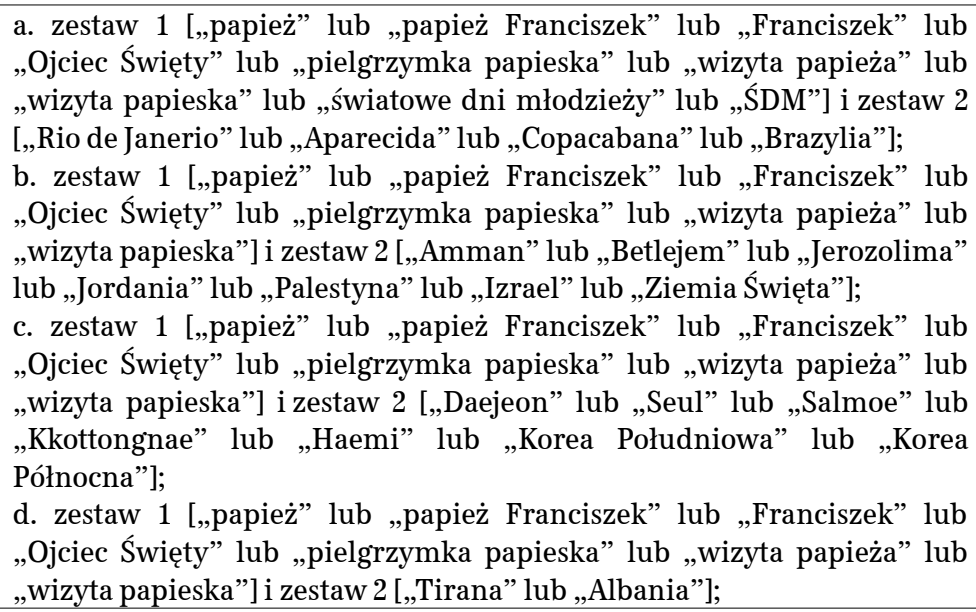 \\
\hline
\end{tabular}

7 Newspoint to serwis monitorujący Internet, najczęściej komercyjnie, dla reklamodawców oraz podmiotów prowadzących działalność gospodarczą w Internecie. Jest to informatyczny system do monitoringu Internetu, mediów społecznościowych i tradycyjnych. Prowadzi analizy w oparciu o metody ilościowe i jakościowe, m.in. analizę treści, CAWI, FGI, IDI. Monitoruje serwisy www, portale internetowe, blogi, fora, serwisy społecznościowe (np. Facebook), mikroblogi (np. Twitter) i inne serwisy. Wykorzystywany do badań naukowych nad Internetem i na temat użytkowników Internetu. Newspoint należy do Międzynarodowego Stowarzyszenia Pomiaru i Oceny Komunikacji (Association for Measurement and Evaluation of Communication, AMEC), certyfikującego jakość przeprowadzanych analiz. 


\begin{tabular}{|c|c|}
\hline & $\begin{array}{l}\text { e. zestaw } 1 \text { [„„papież” lub „papież Franciszek” lub „Franciszek” lub } \\
\text { „Ojciec Święty” lub „pielgrzymka papieska” lub „wizyta papieża” lub } \\
\text { „wizyta papieska”] i zestaw } 2 \text { [,,Strasburg” lub „Francja” lub „Parlament } \\
\text { Europejski” lub „PE”]; } \\
\text { f. zestaw } 1 \text { [,„papież” lub „papież Franciszek” lub „Franciszek” lub } \\
\text { „Ojciec Święty” lub „pielgrzymka papieska” lub „wizyta papieża” lub } \\
\text { „wizyta papieska”] i zestaw 2 [,,Ankara” lub „Stambuł” lub „Turcja”]; }\end{array}$ \\
\hline $\begin{array}{l}\text { 9. Jednostka anali- } \\
\text { zy: }\end{array}$ & dowolne słowo z zestawu 1 plus dowolne słowo z zestawu 2; \\
\hline $\begin{array}{l}\text { 10. Liczba analizowa- } \\
\text { nych artykułów: }\end{array}$ & $\begin{array}{l}\text { a. } 99 ; \\
\text { b. } 60 ; \\
\text { c. } 49 ; \\
\text { d. } 16 ; \\
\text { e. } 25 ; \\
\text { f. } 27 ; \Sigma=276\end{array}$ \\
\hline
\end{tabular}

Tab. 1. Metodologia pierwszego etapu prowadzenia badania.

Źródło: opracowanie własne.

\subsection{2-29 lipca 2013 r. Brazylia}

Papież Franciszek odbył pierwszą podróż apostolską do Brazylii. Jej najważniejszym celem była obecność na Światowych Dniach Młodzieży w Rio de Janerio w dniach 23-26 lipca 2013 r. Odwiedził też sanktuarium maryjne w Aparecida. W stolicy kraju odwiedzał favele. Główna Msza św. została odprawiona na plaży Copacabana. Ze względu na Światowe Dni Młodzieży, jak i to, że była to pierwsza pielgrzymka tego papieża, wydaje się, że powinna wzbudzać zainteresowanie środków społecznego przekazu obecnych w mediach. W analizowanych portalach opublikowano 99 tekstów na ten temat.

\subsubsection{Termin i częstotliwość publikacji}

Pierwszym newsem opublikowanym w badanym czasie była informacja z 21 czerwca 2013 r., zamieszczona na www.wp.pl, a która dotyczyła exposé prezydenta Brazylii dotyczącego problemów z organizacją pielgrzymki i ŚDM ${ }^{8}$, a ostatnią wiadomość na www.onet.pl z 29 sierpnia 2013 r., która podsumowywała wizytę, a jednocześnie szczegółowo komentowała przyznanie organizacji kolejnych ŚDM Krakowowi ${ }^{9}$. W mediach świeckich zauważalne jest położenie akcentu na wiadomości mogące wzbudzić emocje, a także brak szerszych zapowiedzi pielgrzymki czy też pogłębionych komentarzy po upływie miesiąca lub później. Najwięcej informacji opublikowano w ciągu dwóch tygodni przed papieską podróżą apostolską (31), a także w jej trakcie (59). Po niej informacji podsumowujących, a w zasadzie w większości informujących o przyznaniu Krakowowi kolejnych ŚDM, było osiem.

8 Zob. [b.a.], Masowe demonstracje w Brazylii. Prezydent milczy,

http://www.wiadomosci.wp.pl/kat,1356,wid,15754649,martykul.html?ticaid=116ca3 (dostęp 7.04.2016 r.).

9 Zob. J. Kubica, być jak crioca, http://www.tygodnik.onet.pl/32,0,81353,byc_jak_carioca,artykul.html (dostęp 7.04.2016 r.). 


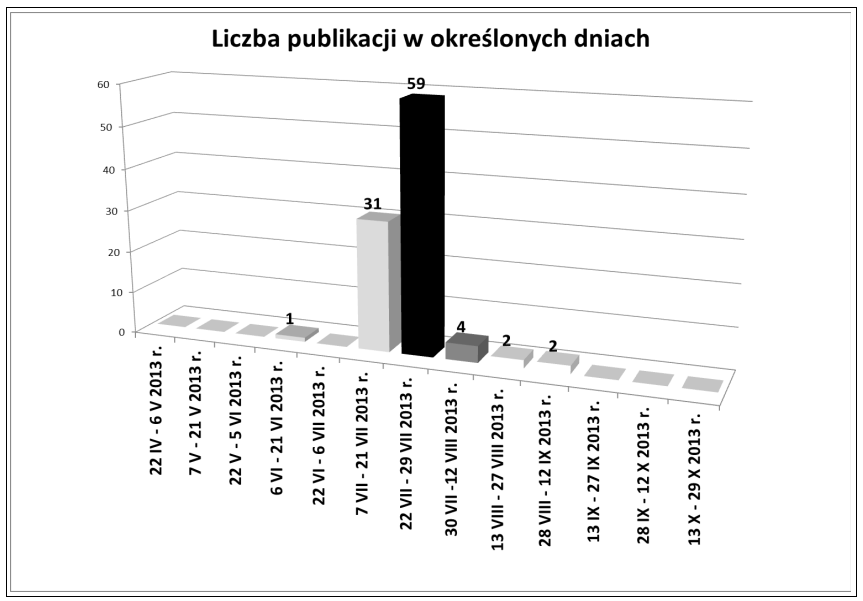

Wyk. 1. Liczba publikacji na temat wizyty papieża Franciszka w Brazylii w polskich portalach, według terminu publikacji, $\mathrm{N}=99$.

Źródło: Newspoint.

\subsubsection{Miejsce publikacji}

Najwięcej artykułów na temat tej pielgrzymki opublikował portal www.onet.pl (41), co daje mu około $42 \%$ udziału wśród wszystkich artykułów na ten temat opublikowanych w wybranych do analizy serwisach i zgromadzonych za pomocą systemu Newspoint. Najmniej informacji opublikowały www.fakt.pl i www.o2.pl, które nie były zainteresowane wydarzeniem.

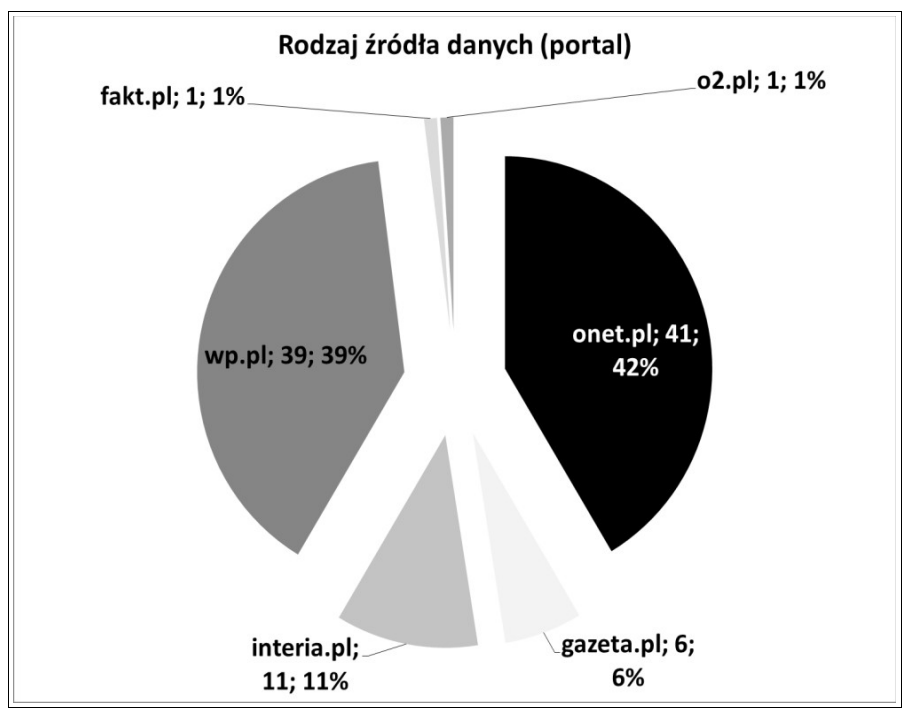

Wyk. 2. Liczba publikacji na temat wizyty papieża Franciszka w Brazylii w polskich portalach, według miejsca publikacji, $\mathrm{N}=99$. Źródło: Newspoint. 


\subsection{Rodzaj publikacji}

Kolejnym etapem prowadzonych badań było określenie sposobu komunikowania o tej pielgrzymce. Publikowane treści zostały podzielona na: pozytywne, neutralne i negatywne za względu na ich wydźwięk. Z przeprowadzonych analiz wynika, że aż $2 / 3$ opublikowanych informacji było pozytywnych.

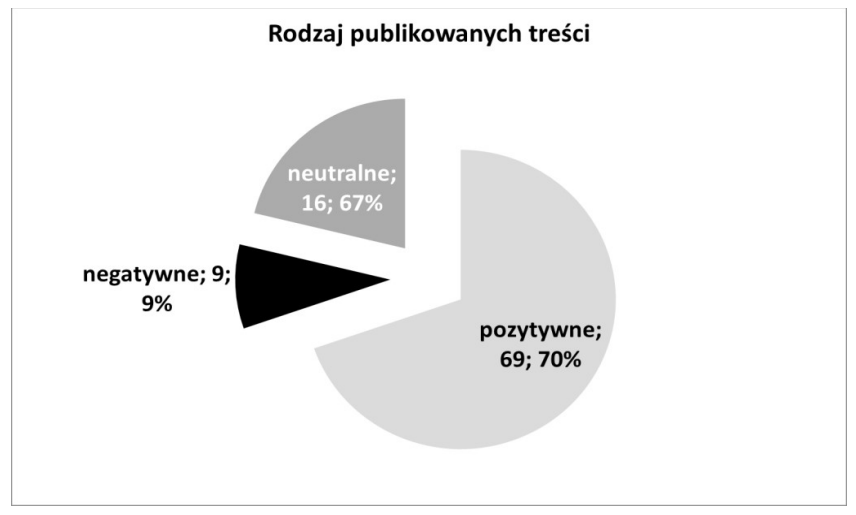

Wyk. 3. Liczba publikacji na temat wizyty papieża Franciszka w Brazylii w polskich portalach, według rodzaju publikacji, N=99. Źródło: Newspoint.

\subsubsection{Rodzaj i miejsce publikacji}

Udział negatywnych i neutralnych informacji był analogiczny wśród poddawanych analizie portali, choć wyjątkiem wydaje się być www.interia.pl, gdzie udział artykułów o wydźwięku pozytywnym prawie pokrywa się z liczbą publikacji negatywnych i neutralnych.

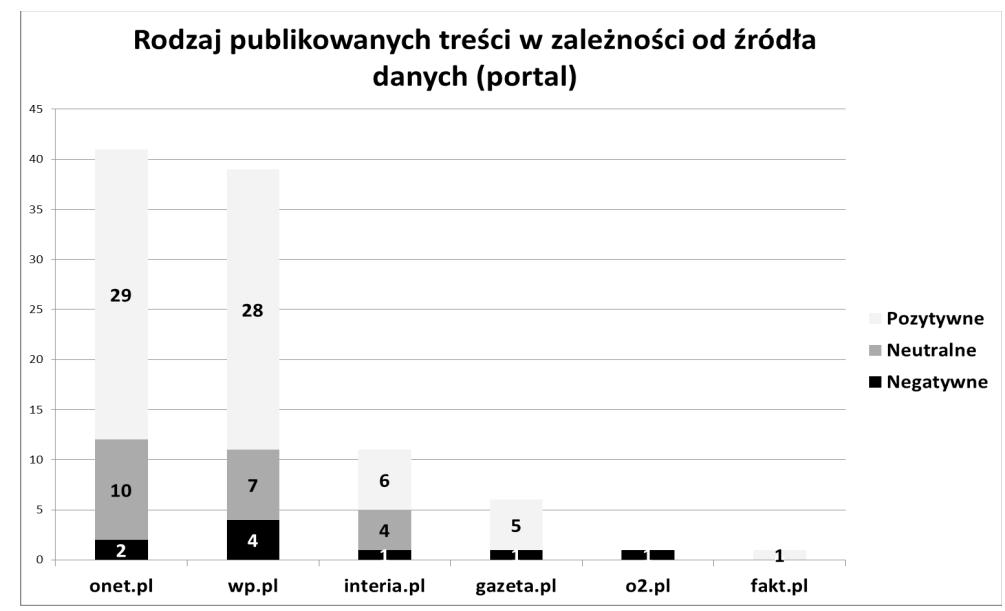

Wyk. 4. Liczba publikacji na temat wizyty papieża Franciszka w Brazylii w polskich portalach, według rodzaju i miejsca publikacji, N=99. Źródło: Newspoint. 
Większość badanych portali internetowych posługuje się informacjami zaczerpniętymi z PAP i KAI. Jedynie portal www.onet.pl publikował materiały miejscowego korespondenta. Negatywne w wydźwięku publikacje pojawiały się przed samą pielgrzymką i dotyczyły starć z miejscowymi służbami bezpieczeństwa, niedokończonej infrastruktury pielgrzymkowej, kosztów pobytu papieża czy demonstracji środowisk LGBT ${ }^{10}$. W trakcie spotkania pojawiały się w zasadzie pozytywne bądź neutralne sprawozdania z wydarzeń. Nie skupiały się one na analizie sytuacji Kościoła czy treści papieskiego przekazu, ale obecności papieża wśród najuboższych, w domach opieki czy ośrodkach dla młodocianych przestępców lub jego wypowiedzi dotyczących osób LGBT. Materiały publikowane po wydarzeniu w zasadzie nie podsumowywały pielgrzymki, a akcentowały przyznanie Krakowowi organizacji kolejnych Światowych Dni Młodzieży oraz długów organizatorów ${ }^{11}$. Warto zauważyć, że wśród negatywnych komentarzy nie ma takich, które bezpośrednio dotykają osoby papieża, ale komentują tak infrastrukturę wizyty apostolskiej czy kontestują nauczanie Kościoła w jakieś kwestii.

\subsection{4-26 maja 2014 r. - Jordania, Palestyna, Izrael (Ziemia Święta)}

Druga podróż apostolska papieża Franciszka do Jordanii, Palestyny i Izraela odbyła się w dniach od 24 do 26 maja 2014 r., po prawie rocznej przerwie. Obejmowała trzy miasta: Amman, Betlejem i Jerozolimę. W trakcie wizyty papież spotkał się z patriarchą Bartłomiejem i przedstawicielami różnych wspólnot chrześcijańskich. Szczególnie nawiązywał do dialogu międzyreligijnego i do wprowadzania pokoju. W analizowanych mediach opublikowano 60tekstów na jej temat.

\subsubsection{Termin i częstotliwość publikacji}

Pierwszym newsem opublikowanym w badanym zakresie czasowym była informacja z 27 marca 2014 r., zamieszczona na www.interia.pl, która szczegółowo przedstawiała plan pielgrzymki papieża Franciszka ${ }^{12}$, a ostatnią w serwisie www.onet.pl z 8 sierpnia

10 Zob. [b.a.], Gaz łzawiący podczas protestu przeciwko wizycie papieża, http://www.fakty.interia.pl/raport-nowy-papiez/aktualnosci/news-gaz-lzawiacy-podczas-protestu-przeciwko-wizyciepapieza,nId,998158 (dostęp 7.04.2013 r.); [b.a.], Starcia w Rio de Janeiro, http://www.wiadomosci.wp.pl/mgaleria.html?gid=15836237\&, (dostęp 7.04.2013 r.); [b.a.], Chcą sprowokować Franciszka, http://www.wiadomosci.wp.pl/mgaleria.html?gid=15850034\& (dostęp 7.04.2013 r.).

Zob. P. Henzel, Możliwy podział w Kościele? Polska ma kłopot z Franciszkiem, http://www.wiadomosci.onet.pl/tylko-w-onecie/papiez-zrywa-z-zasada-jana-pawla-ii-to-klopot-dla-polski/5erfj (dostęp 7.04.2013 r.); J. Kowalski, Światowe Dni Młodzieży skończyły się finansową klapą. Kościół ratuje się, sprzedając Dom Biednych, http://www.gazeta.pl/1,76842,14514810,Swiatowe_Dni_Mlodziezy_skonczyly_sie_finansowa_klapa_html (dostęp 7.04.2013 r.). .pl/news-watykan-oglosil-program-pielgrzymki-papieza-do-ziemi-swietej,nId,1399090 (dostęp 9.04.2016 r.). 
2014 r., która podsumowywała wizytę. Pisano o dwóch ścianach płaczu: jednej przy Świątyni Jerozolimskiej, a drugiej oddzielającej terytorium palestyńskie od Izraela ${ }^{13}$. W mediach świeckich zauważalne jest położenie akcentu na wiadomości mogące wzbudzić emocje, a także brak szerszych zapowiedzi pielgrzymki w formie komentarzy wprowadzających czy też pogłębionych komentarzy podsumowujących, dokonywanych z dłuższej perspektywy czasowej niż miesiąc. Jedynym wyjątkiem jest redakcja www.onet.pl, korzystająca z serwisu „Tygodnika Powszechnego”. Najwięcej informacji opublikowano w ciągu dwóch tygodni przed papieska podróżą apostolską (15), a także w jej trakcie (28). Informacji podsumowujących po niej było 14 .

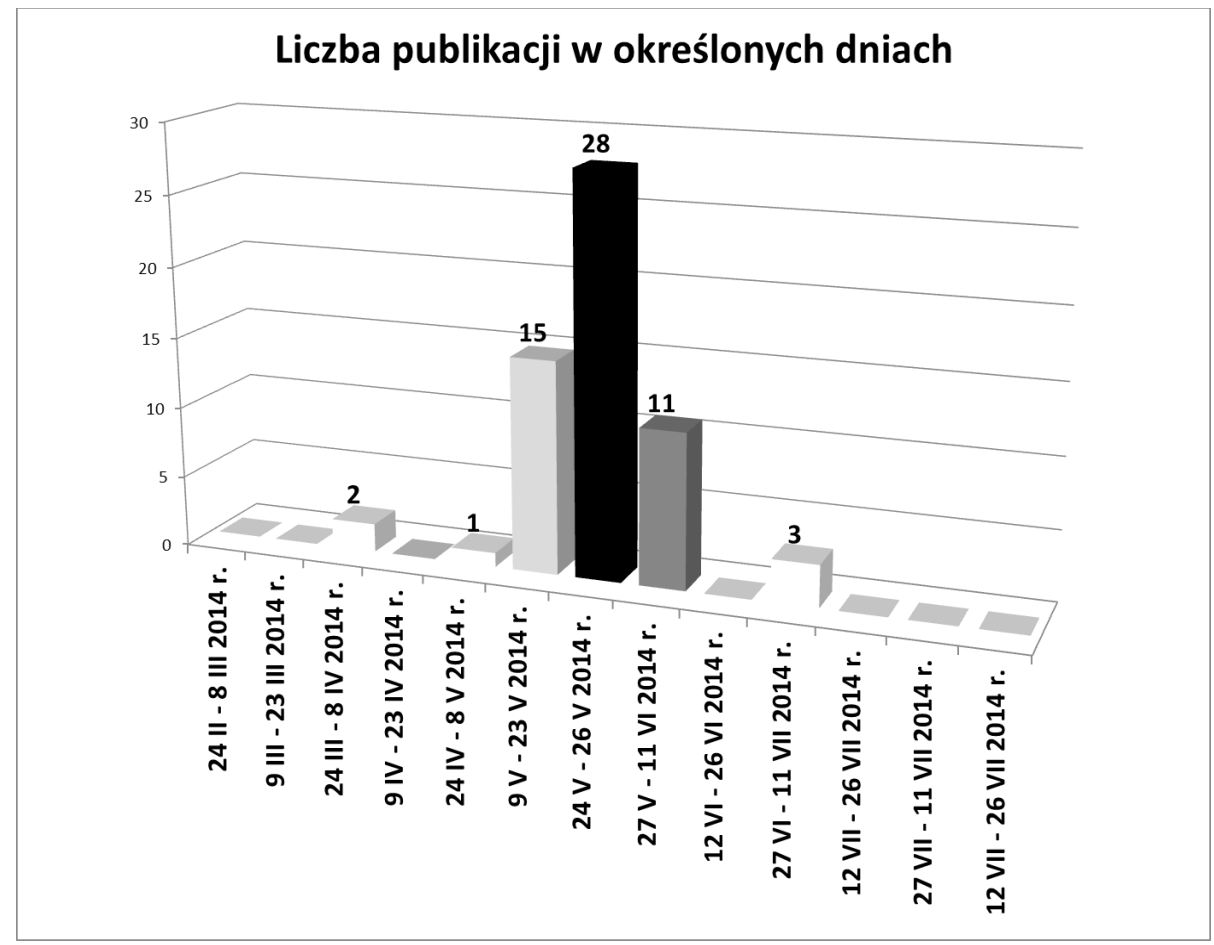

Wyk. 5. Liczba publikacji na temat wizyty papieża Franciszka w Ziemi Świętej w polskich portalach, według terminu publikacji, $\mathbf{N}=60$.

Źródło: Newspoint.

\subsubsection{Miejsce publikacji}

Najwięcej informacji na temat tej pielgrzymki opublikował portal www.onet.pl (29), co daje mu udział około $48 \%$ w rynku informacji internetowych na ten temat. Najmniej informacji opublikowały www.fakt.pl (1) i www.02.pl_(0), które nie były zainteresowane wydarzeniem.

13 Zob. M. Zając, Dwie ściany płaczu, http://www.tygodnik.onet.pl/wiara/dwie-sciany-placzu/d4t4e (dostęp 9.04.2016 r.). 


\section{KOŚCIÓŁ I MEDIA}

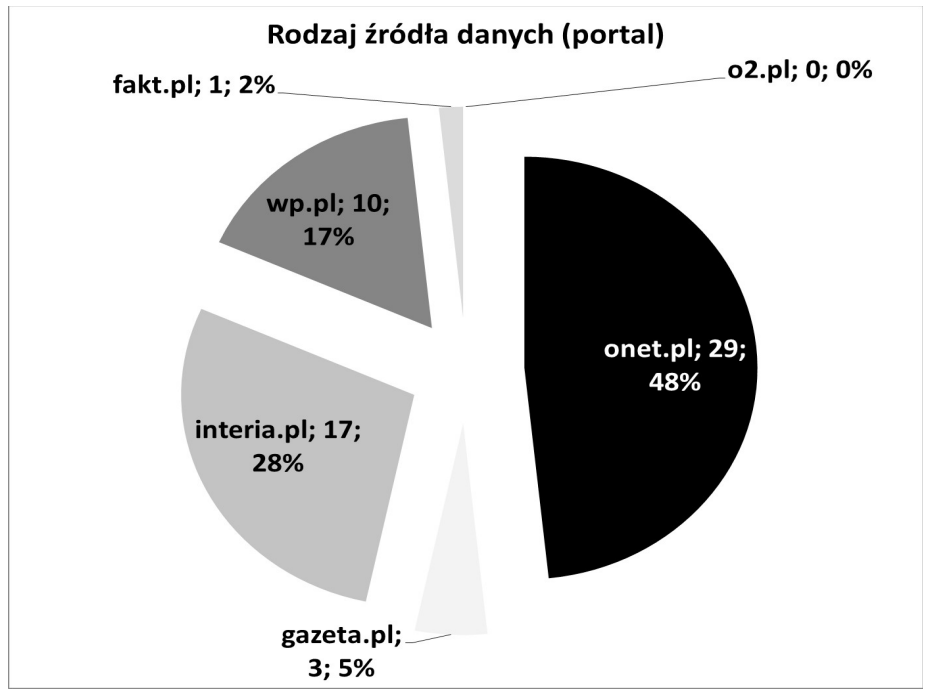

Wyk. 6. Liczba publikacji na temat wizyty papieża Franciszka w Ziemi Świętej w polskich portalach, według miejsca publikacji, $\mathrm{N}=60$.

Źródło: Newspoint.

\subsubsection{Rodzaj publikacji}

Kolejnym etapem prowadzonych badań było określenie sposobu komunikowania o tej pielgrzymce. Publikowane treści zostały podzielona na pozytywne, neutralne i negatywne, za względu na ich wydźwięk. Z przeprowadzonych analiz wynika, że 5/6 opublikowanych informacji było pozytywnych (33) lub neutralnych (17).

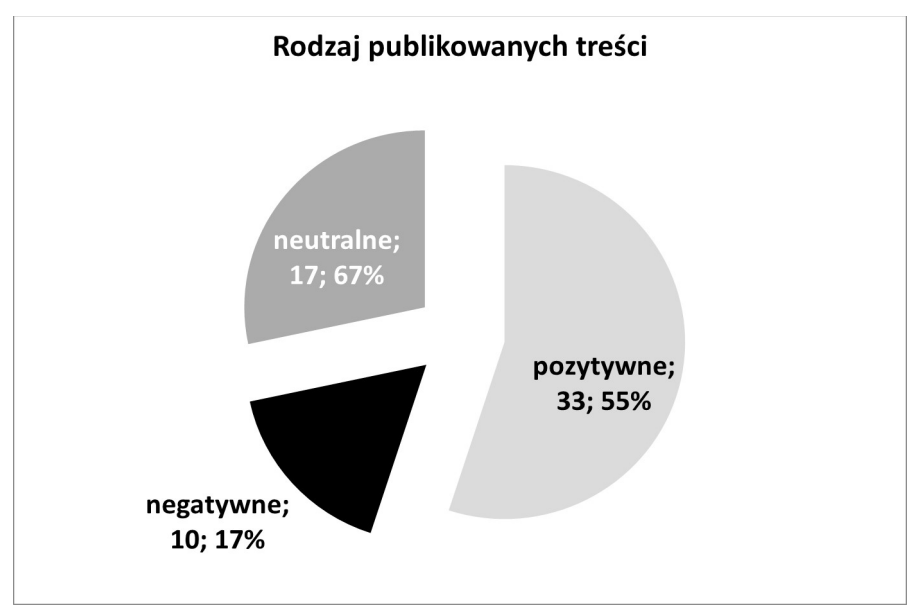

Wyk. 7. Liczba publikacji na temat wizyty papieża Franciszka w Ziemi Świętej w polskich portalach, według rodzaju publikacji, $\mathrm{N}=60$.

Źródło: Newspoint. 


\subsubsection{Rodzaj i miejsc publikacji}

Udział negatywnych i neutralnych informacji był wśród poddawanych analizie portali porównywalny, choć wyjątkiem wydaje się być www.wp.pl, gdzie udział artykułów o wydźwięku pozytywnym jest niewiele wyższy niż udział publikacji o wydźwięku negatywnym i neutralnym.

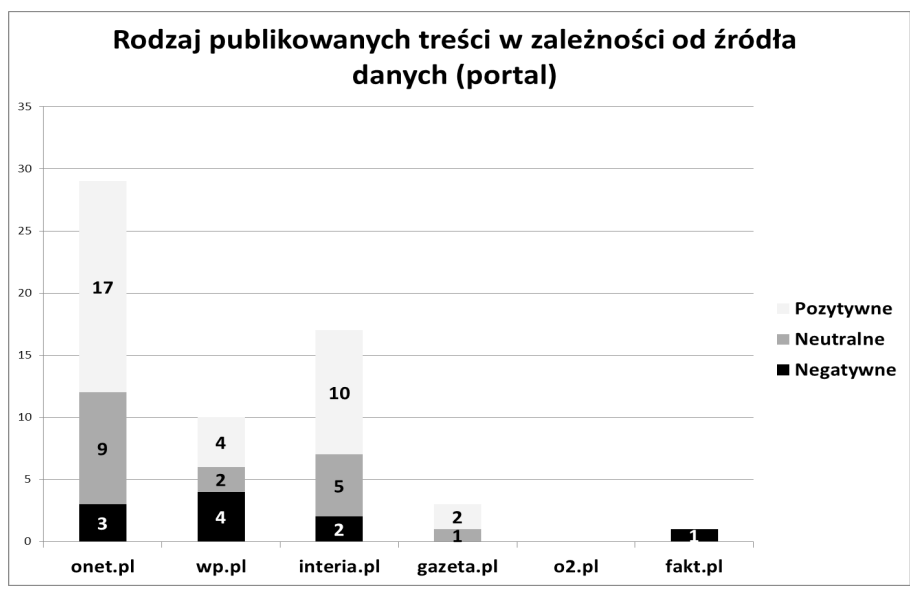

Wyk. 8. Liczba publikacji na temat wizyty papieża Franciszka w Ziemi Świętej w polskich portalach, według rodzaju i miejsca publikacji, $\mathrm{N}=60$.

Źródło: Newspoint.

Większość badanych portali internetowych posługuje się informacjami zaczerpniętymi z PAP i KAI. Jedynie portal www.onet.pl publikował materiały miejscowego korespondenta, a niektóre korzystały z materiałów RAI, która wysłała reportera do Ziemi Świętej. Publikacje o wydźwięku negatywnym pojawiały się przed samą pielgrzymką. Dotyczyły zamieszek i drobnych gestów dotyczących dialogu międzyreligijnego na linii: żydzi - muzułmanie - chrześcijanie, np. napisów na ścianach świątyni ${ }^{14}$. W trakcie spotkania pojawiały się w zasadzie pozytywne bądź neutralne sprawozdania z wydarzeń. Nie skupiały się one na analizie sytuacji Kościoła czy treści papieskiego przekazu, ale na samej obecności papieża w Ziemi Świętej, gdzie trwa wiele konfliktów na tle religijnym czy rasowym. Materiały publikowane po wydarzeniu tylko sporadycznie podsumowywały wizytę papieską ${ }^{15}$. Warto zauważyć, że wśród negatywnych komentarzy nie ma takich, które bezpośrednio dotykają osoby papieża, ale komentują agresję radykalnych stronnictw żydowskich czy inne przejawy nieprzychylności wobec Ojca Świętego.

14 Zob. [b.a.], Antychrześcijański napis na placówce łacińskiego patriarchatu Jerozolimy, http://www.wiadomosci.wp.pl/kat,1356,wid,16589820,martykul.html (dostęp 9.04.2016 r.); W. Cegielski, Akty wandalizmu przed wizytą papieża, http://www.fakty.interia.pl/swiat/news-izrael-akty-wandalizmu-przed-wizyta-papieza,nId,1423346 (dostęp 9.04.2016 r.).

15

Zob. M. Zając, art.cyt. 

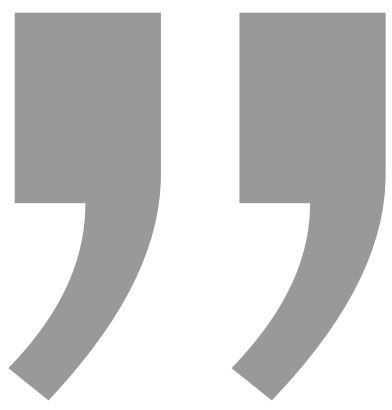

\section{W trakcie spotkania pojawiały się} w zasadzie pozytywne bądź neutralne sprawozdania z wydarzeń. Nie skupiały się one na analizie sytuacji Kościoła czy treści papieskiego przekazu, ale na samej obecności papieża w Ziemi Świętej, gdzie trwa wiele konfliktów na tle religüjnym czy rasowym.

\subsection{4-18 sierpnia 2014 r. - Korea Południowa}

Trzecia podróż apostolska papieża Franciszka do Korei Południowej odbyła się w dniach od 14 do 18 sierpnia 2014 r. Obejmowała ona pięć miast: Daejeon, Seul, Salmoe, Kkottongnae i Haemi. W trakcie wizyty Ojciec Święty wziął udział w obchodach VI Dnia Młodzieży Azji oraz beatyfikował Pawła Yun Ji-chunga i 123 towarzyszy zamordowanych w Korei $\mathrm{z}$ nienawiści do wiary w latach 1791-1888. Franciszek był drugim papieżem odwiedzającym Koreę. Na analizowanych portalach zostało opublikowanych 49 tekstów na jej temat.

\subsubsection{Termin i częstotliwość publikacji}

Pierwszym newsem opublikowanym w badanym czasie była informacja z 15 lipca 2014 r., zamieszczona na www.onet.pl, która omawiała zaproszenie katolików z Korei Północnej na spotkanie z papieżem ${ }^{16}$, a ostatnim relacja $\mathrm{z}$ tradycyjnej konferencji prasowej z papieżem w samolocie i omówienie kolejnych prób rakiet balistycznych Korei Północnej w serwisie www.onet.pl z 27 sierpnia i 1 września 2014 r. ${ }^{17}$. W mediach świeckich zauważalna jest położenie na wiadomości mogące wzbudzić emocje, a także brak komentarzy wprowadzających czy też pogłębionych komentarzy podsumowujących, które by były dokonywane po czasie dłuższym niż miesiąc. Relacje związane z pielgrzymką ukazywały się w zasadzie jedynie w okresie jej trwania. Najwięcej informacji opublikowano w ciągu dwóch tygodni przed papieska podróżą apostolską (9), a także w jej trakcie (33). Z liczby informacji i ich porównania z poprzednimi podróżami apostolskimi można wywnioskować, że zainteresowanie pielgrzymką było niewielkie.

16 Zob. [Bez autora], Korea Płd. prosi Pjongjang o wysłanie katolików na wizytę papieża, 15 VII 2014 r., w: http://www.wiadomosci.onet.pl/swiat/korea-pld-prosi-pjongjang-o-wyslanie-katolikow-na-wizyte-papieza/qbclc, [dostęp 09 IV 2016 r.].

17 Zob. [Bez autora], Czy papież jest "Ojcem Świętym"?, 27 VIII 2014 r, w:

http://www.tygodnik.onet.pl/wiara/czy-papiez-jest-ojcem-swietym/wlb1e, [dostęp 09 IV 2016 r.]; [Bez autora], Korea Płn. przeprowadziła kolejny test $z$ rakietą krótkiego zasięgu, 01 IX 2014 r., w:

http://www.wiadomosci.onet.pl/swiat/korea-pln-przeprowadzila-kolejny-test-z-rakieta-krotkiego-zasiegu/3q7yf, [dostęp 09 IV 2016 r.]. 


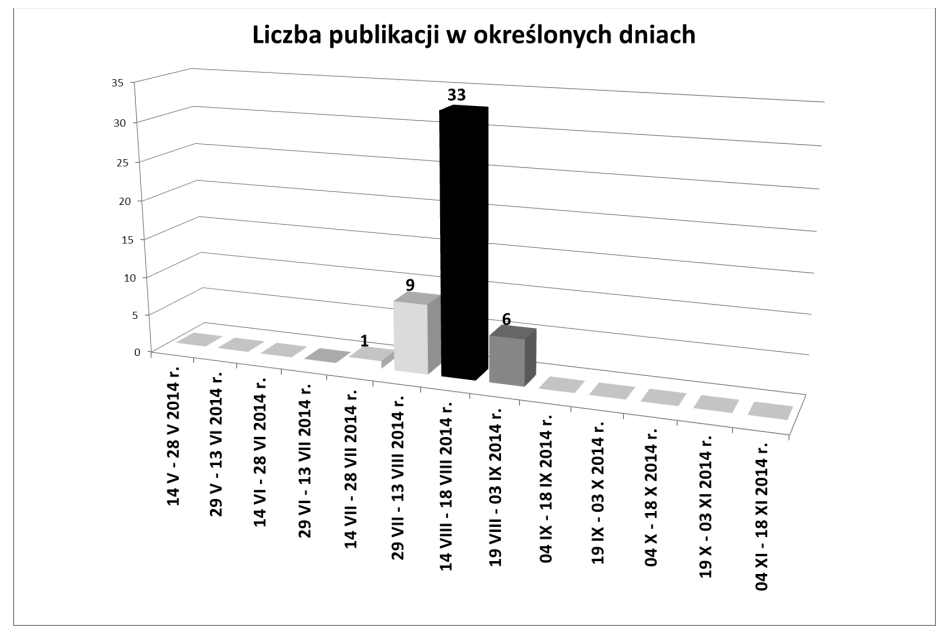

Wyk. 9. Liczba publikacji na temat wizyty papieża Franciszka w Korei Południowej w polskich portalach, według terminu publikacji, $\mathrm{N}=49$.

Źródło: Newspoint.

\subsubsection{Miejsce publikacji}

Z przeprowadzonych analiz wynika, że najwięcej informacji na temat tej pielgrzymki opublikowały portale www.interia.pl i www.onet.pl (po 20), co daje im udział około $41 \%$ w rynku informacji internetowych na ten temat (razem 82\%). Najmniej informacji opublikowały www.fakt.pl (1) i www.o2.pl (0), które nie były zainteresowane wydarzeniem.

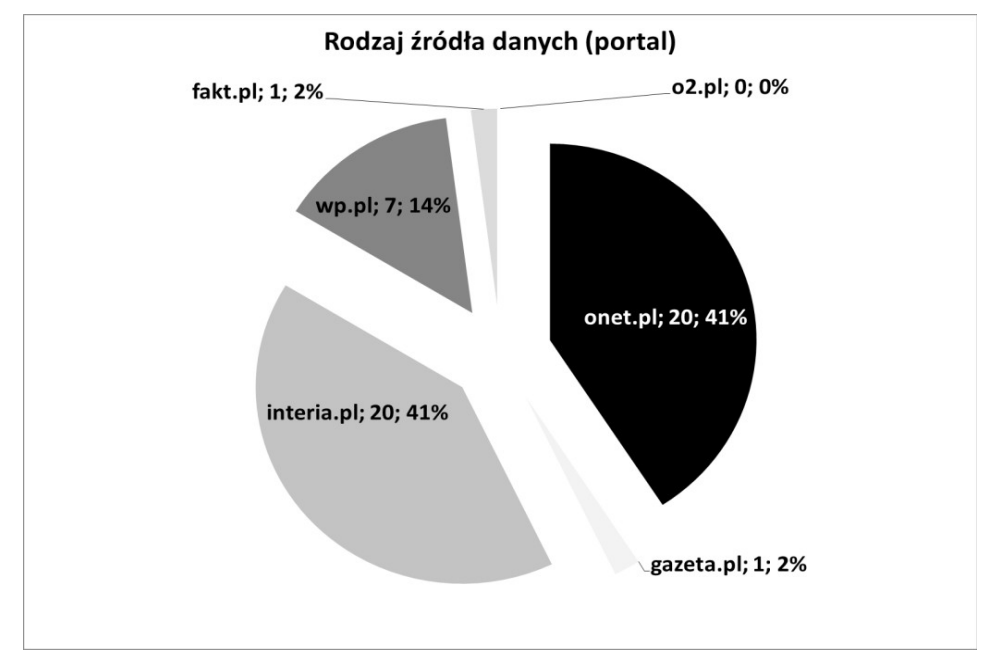

Wyk. 10. Liczba publikacji na temat wizyty papieża Franciszka w Korei Południowej w polskich portalach, według miejsca publikacji, $\mathrm{N}=49$.

Źródło: Newspoint. 


\section{KOŚCIÓŁ I MEDIA}

\subsubsection{Rodzaj publikacji}

Kolejnym etapem prowadzonych badań było określenie sposobu komunikowania o tej pielgrzymce. Z przeprowadzonych analiz wynika, że 5/6 opublikowanych informacji było pozytywnych (29) lub neutralnych (13).

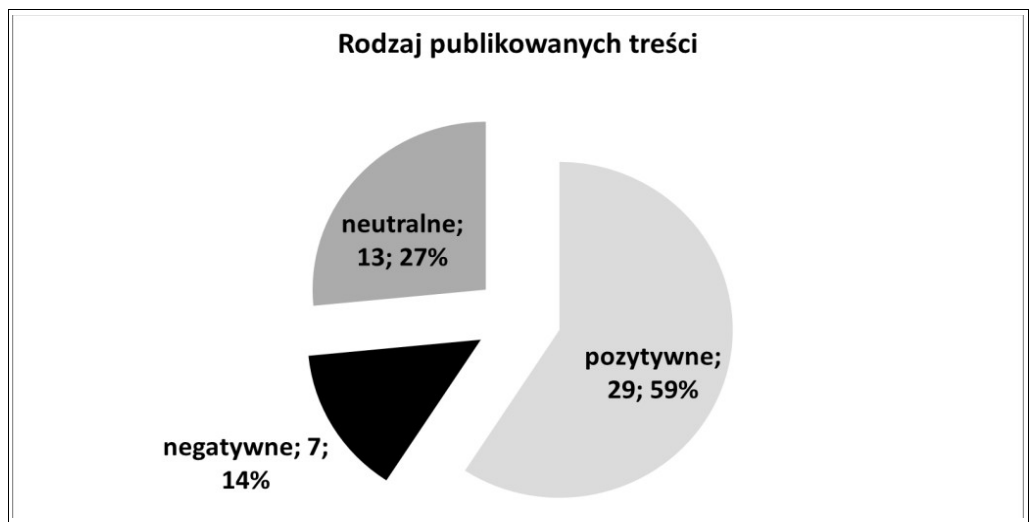

Wyk. 11. Liczba publikacji na temat wizyty papieża Franciszka w Korei Południowej w polskich portalach, według rodzaju publikacji, $\mathrm{N}=49$.

Źródło: Newspoint.

\subsubsection{Rodzaj i miejsc publikacji}

Udział negatywnych i neutralnych informacji w portalach poddawanych analizie był porównywalny, choć wyjątkiem wydaje się być www.fakt.pl, który opublikował tekst związany $\mathrm{z}$ analizowaną pielgrzymką o negatywnym wydźwięku.

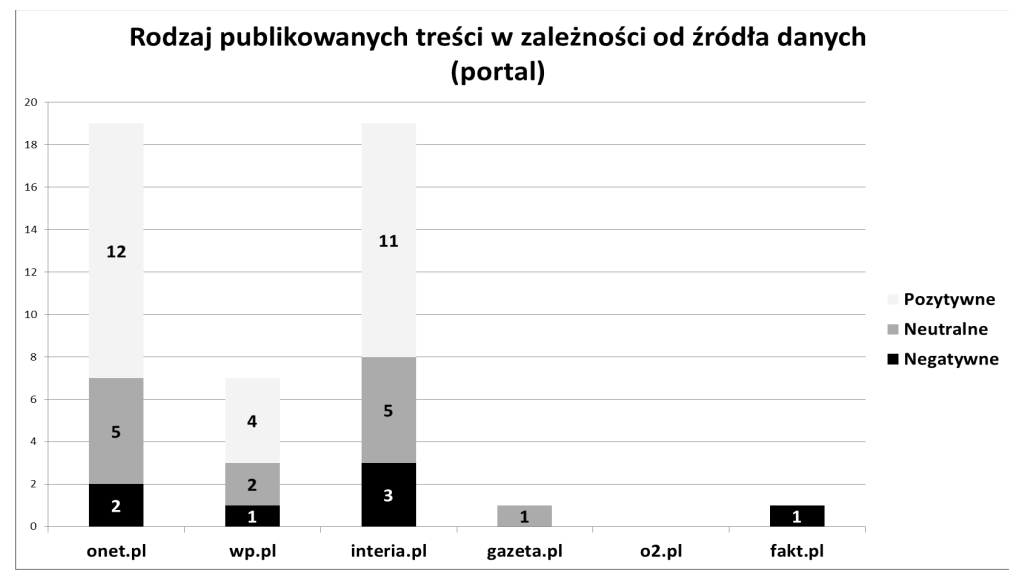

Wyk. 12. Liczba publikacji na temat wizyty papieża Franciszka w Korei Południowej w polskich portalach, według rodzaju i miejsca publikacji, $\mathrm{N}=49$.

Źródło: Newspoint. 
Większość badanych portali internetowych posługuje się informacjami zaczerpniętymi z PAP i KAI, a część newsów jest identyczna z informacjami agencyjnymi bądź kosmetycznie zmieniona. Niektóre portale: www.interia.pl, www.onet.pl i www.wp.pl korzystały z materiałów RAI, która wysłała do Korei reportera. Publikacje o wydźwięku negatywnym pojawiały się bezpośrednio przed pielgrzymką i dotyczyły wystrzelenia pocisków rakietowych przez reżim Kim Dzong Una oraz utrudnień, które mnożyły służby bezpieczeństwa, by nie dopuścić do spotkania z papieżem określonych grup społecznych, a także koniecznością usunięcia rodzin ofiar katastrofy promu Sewol z placu, na którym miała być sprawowana Msza św. ${ }^{18}$. W trakcie spotkania pojawiały się pozytywne bądź neutralne sprawozdania z wydarzeń. Nie skupiały się one na analizie sytuacji Kościoła czy treści papieskiego przekazu, ale na kontekście politycznym. Materiały publikowane po wydarzeniu tylko sporadycznie podsumowywały wizytę papieską. Warto zauważyć, że wśród negatywnych komentarzy nie ma takich, które bezpośrednio dotykają osoby papieża, ale komentują: wystrzelenie pocisków rakietowych przed przelotem papieża nad terytorium Korei Północnej, zakaz udziału katolików z tego kraju w papieskiej pielgrzymce, czy utrudnianie dostępu do papieża Franciszka rodzinom ofiar katastrofy promu Sewol, do której doszło 16 kwietnia 2014 r., a nawet sugestie, że papież może przyczynić się do wybuchu wojny ${ }^{19}$.

\subsection{1 września 2014 r. - Albania}

Podróż apostolska papieża Franciszka do Albanii odbyła się 21 września 2014 r. Obejmowała jedno miasto: Tiranę i trwała jedenaście godzin. Miała podkreślić pokojową koegzystencję chrześcijan i muzułmanów w kraju, w którym ci pierwsi stanowią zdecydowaną mniejszość. Innym powodem było zauważenie prześladowań chrześcijan w latach komunistycznej dyktatury Envera Hodży. W analizowanych portalach opublikowano jedynie 16 tekstów na jej temat, co wynikało z jej krótkotrwałości. Trzy portale nie informowały o niej w ogóle.

\subsubsection{Termin i częstotliwość publikacji}

Pierwszym newsem w badanym czasie była informacja z 16 września 2014 r. opublikowana na portalu www.fakt.pl. Zasugerowano w niej możliwość ataku terrorystyczne-

18 Zob. [b.a.], Rodziny ofiar katastrofy promu nie ustąpią papieżowi, http://www.fakty.interia.pl/swiat/news-rodziny-ofiar-katastrofy-promu-nie-ustapiapapiezowi,nId,1480103 (dostęp 9.04.2016 r.); [b.a.], Korea Płn. odpaliła trzy pociski rakietowe przed wizytą papieża, http://www.wiadomosci.onet.pl/swiat/korea-pln-odpalila-trzy-pociski-rakietowe-przed-wizyta-papieza/9f6pm (dostęp 9.04.2016 r.); [b.a.], Korea Północna odpaliła pięć pocisków rakietowych w dniu wizyty papieża w Korei Południowej,

http://www.wiadomosci.wp.pl/kat,1356,wid,16816194,martykul.html (dostęp 9.04.2016 r.).

Zob. [b.a.], Papież Franciszek podczas powrotu z Korei Południowej poparł użycie siły wobec islamistów, http://www.wiadomosci.onet.pl/swiat/papiez-franciszek-podczas-powrotu-z-korei-poludniowej-poparl-uzycie-sily-wobec/yc0bt (dostęp 9.04.2016 r.); [b.a.], Korea Północna: może dojść do wojny, Waszyngton i Seul planują inwazję, http://www.wiadomosci.onet.pl/swiat/korea-pln-odpalila-trzy-pociskirakietowe-przed-wizyta-papieza/9f6pm (dostęp 9.04.2016 r.); [b.a.], Czy papież jest "Ojcem Świętym"?, http://www.tygodnik.onet.pl/wiara/czy-papiez-jest-ojcem-swietym/wlb1e (dostęp 9.04.2016 r.). 
go, którego ofiarą może paść papież Franciszek ${ }^{20}$. Ostatnia publikacja ukazała się w serwisie www.interia.pl 25 września i była podsumowaniem papieskiej wizyty apostolskiej $^{21}$. Warto zauważyć, że informacje na jej temat były publikowane przez zaledwie dziewięć dni, a redakcje nie informowały szerzej o tym wydarzeniu. Relacje związane z pielgrzymką ukazywały się w zasadzie jedynie w okresie jej trwania. Najwięcej informacji opublikowano w okresie pięciu dni przed papieską podróżą apostolską (8), a także w jej trakcie (7). Zauważalne było nikłe zainteresowanie pielgrzymką.

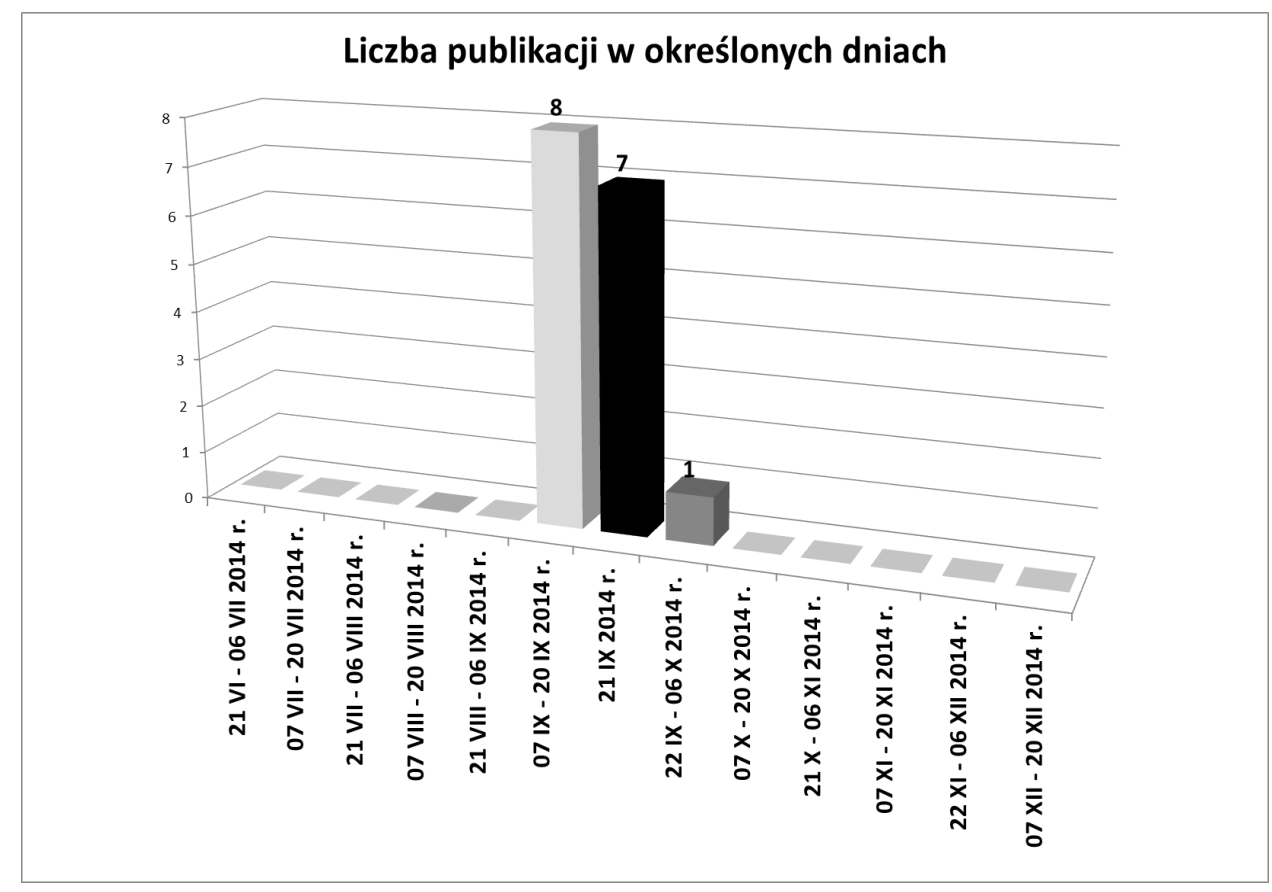

Wyk. 13. Liczba publikacji na temat wizyty papieża Franciszka w Albanii w polskich portalach, wedhug terminu publikacji, $\mathrm{N}=16$.

Źródło: Newspoint.

\subsubsection{Miejsce publikacji}

Najwięcej informacji na temat tej pielgrzymki opublikował portal www.onet.pl (7), co daje mu udział około 44\% w rynku informacji internetowych na ten temat. Najmniej informacji opublikowały www.fakt.pl (1) i www.gazeta.pl i www.o2.pl (0), które nie były zainteresowane wydarzeniem.

20 Zob. [b.a.], Islamiści chcą zabić papieża! Potem atak na Europę, http://www.fakt.pl/wydarzenia/islamisci-chca-zabic-papieza-w-albanii-podczas-pielgrzmki,artykuly,489059.html (dostęp 9.04.2016 r.).

21 Zob. [b.a.], Papieskie przesłanie nadziei, http://www.fakty.interia.pl/raport-nowypapiez/aktualnosci/news-papieskie-przeslanie-nadziei,nId,1505153 (dostęp 9.04.2016 r.). 


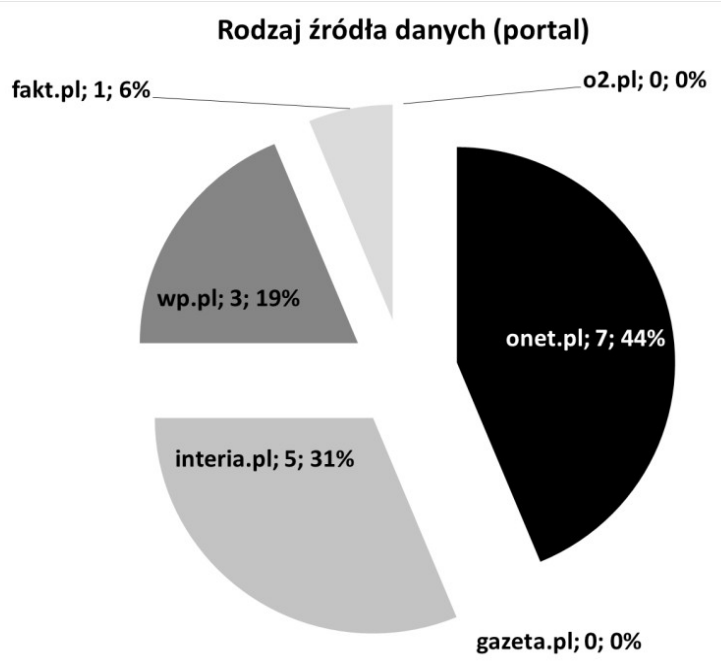

Wyk. 14. Liczba publikacji na temat wizyty papieża Franciszka w Albanii w polskich portalach, według miejsca publikacji, $\mathrm{N}=\mathbf{1 6}$.

Źródło: Newspoint.

\subsubsection{Rodzaj publikacji}

Kolejną analizą było określenie sposobu komunikowania o tej pielgrzymce. Z przeprowadzonych badań wynika, że 8/9 opublikowanych informacji było pozytywnych (11) lub neutralnych (3).

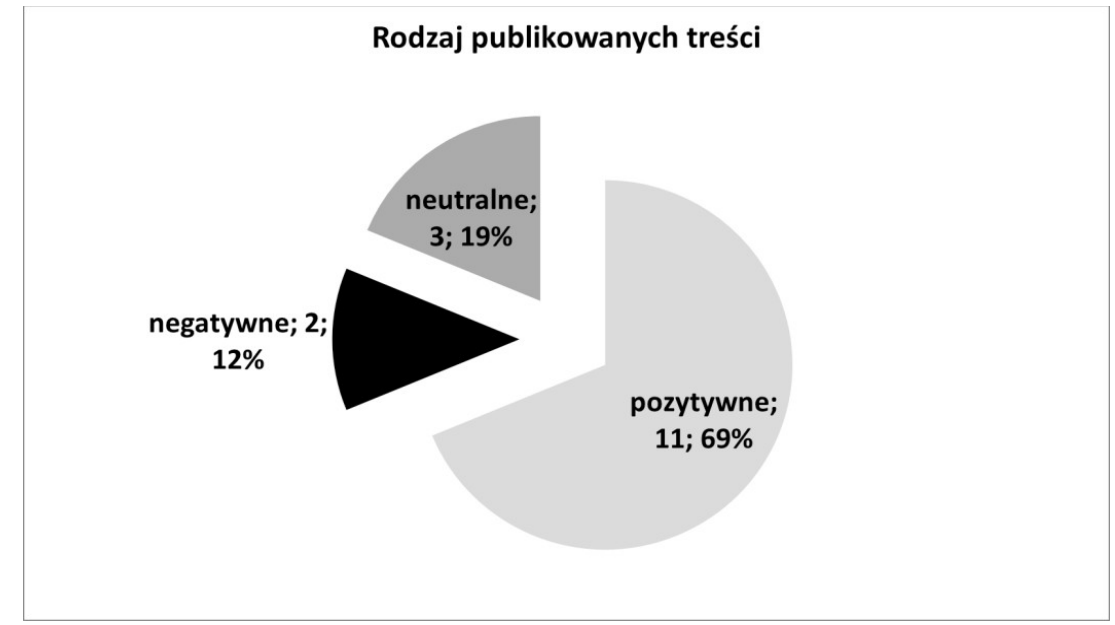

Wyk. 15. Liczba publikacji na temat wizyty papieża Franciszka w Albanii w polskich portalach, według rodzaju publikacji, $\mathrm{N}=16$.

Źródło: Newspoint. 


\subsubsection{Rodzaj i miejsc publikacji}

Udział negatywnych i neutralnych informacji był porównywalny wśród portali poddawanych analizie. Wyjątkiem wydaje się być www.fakt.pl, który opublikował tekst związany $\mathrm{z}$ analizowaną pielgrzymką o negatywnym wydźwięku, sytuując ją $\mathrm{w}$ kontekście zagrożenia terrorystycznego - co jest spowodowane tabloidowym charakterem portalu. Jedyna negatywna informacja z portalu www.interia.pl także dotyczyła tej możliwości.

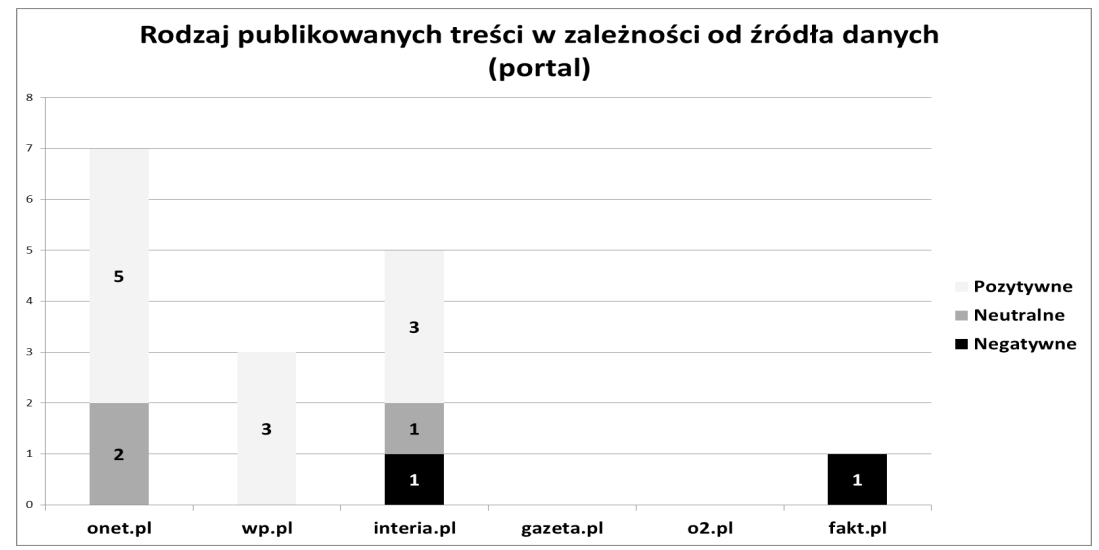

Wyk. 16. Liczba publikacji na temat wizyty papieża Franciszka w Albanii w polskich portalach, według rodzaju i miejsca publikacji, $\mathbf{N = 1 6}$.

Źródło: Newspoint.

Widać wyraźnie, że również w tym wypadku większość badanych portali posługuje się informacjami zaczerpniętymi z PAP i KAI. Publikacje o wydźwięku negatywnym pojawiały się przed samą pielgrzymką i dotyczyły zagrożenia terrorystycznego związanego z Państwem Islamskim ${ }^{22}$. W trakcie pielgrzymki pojawiały się w zasadzie pozytywne bądź neutralne sprawozdania. Nie skupiały się na analizie sytuacji Kościoła czy treści papieskiego przekazu, ale obecności papieża wśród najuboższych czy w domach opieki dla młodocianych przestępców. Materiałów podsumowujących pielgrzymkę w zasadzie nie było ${ }^{23}$.

\subsection{5 listopada 2014 r. - Francja}

Podróż apostolska papieża Franciszka do Strasburga odbyła się 25 listopada 2014 r. 11 października 2013 r. podczas audiencji przewodniczący Parlamentu Europejskiego Martin

22 Zob. [b.a.], Islamiści chcą zabić papieża! Potem atak na Europę, http://www.fakt.pl/wydarzenia/islamisci-chca-zabic-papieza-w-albanii-podczas-pielgrzmki,artykuly,489059.html (dostęp 9.04.2016 r.); [b.a.], Papież zagrożony atakiem terrorystycznym?, http://www.fakty.interia.pl/raport-nowy-papiez/aktualnosci/news-papiez-zagrozony-atakiem-terrorystycznym,nId,1500625 (dostęp 9.04.2016 r.).

Zob. [b.a.], Papież Franciszek powrócił z Albanii do Rzymu,

http://www.wiadomosci.wp.pl/kat,1356,wid,16900243,martykul.html (dostęp 9.04.2016 r.); [b.a.], Papieskie przesłanie nadziei, http://www.fakty.interia.pl/raport-nowy-papiez/aktualnosci/news-papieskie-przeslanie-nadziei,nId,1505153 (dostęp 9.04.2016 r.). 
Schulz zaprosił papieża Franciszka, by wygłosił przemówienie. Ten uczynił to w 25. rocznicę wizyty Jana Pawła II w Parlamencie Europejskim. Mówił o przeobrażeniach świata, który nie jest już europocentryczny, o pomocy imigrantom, a także o zagwarantowaniu przyszłości młodemu pokoleniu. Była to najkrótsza podróż apostolska Franciszka. Trwała tylko 4 godziny. W analizowanych portalach opublikowano zaledwie 25 tekstów, na jej temat.

\subsubsection{Termin i częstotliwość publikacji}

Pierwszym newsem opublikowanym w badanym czasie była informacja z 11 września 2014 r., zamieszczona na portalu www.onet.pl. Była to zapowiedź prasowa potwierdzona u rzecznika Watykanu, o planowanej wizycie papieża Franciszka w Parlamencie Europejskim ${ }^{24}$. Ostatnia publikacja ukazała się 6 grudnia w serwisie www.interia.pl i była podsumowaniem papieskiej wizyty w PE, z zaznaczeniem podziału Europy na dwa bloki polityczno-religijne i dążenia do polepszenia wzajemnych stosunków z Cerkwią Prawosławną ${ }^{25}$. Warto zauważyć, że informacje na jej temat były publikowane przez zaledwie trzy dni (pomijając informację zapowiadająca i analizującą stosunki katolicko-prawosławne), a redakcje nie informowały szerzej o tym wydarzeniu. Relacje związane z pielgrzymką ukazywały się w zasadzie jedynie w okresie jej trwania. Najwięcej informacji zapowiadających to wydarzenie opublikowano ostatniego dnia przed papieską podróżą apostolską (3) i w jej trakcie (16). Zauważalne było nikłe zainteresowanie pielgrzymką w krajowych mediach.

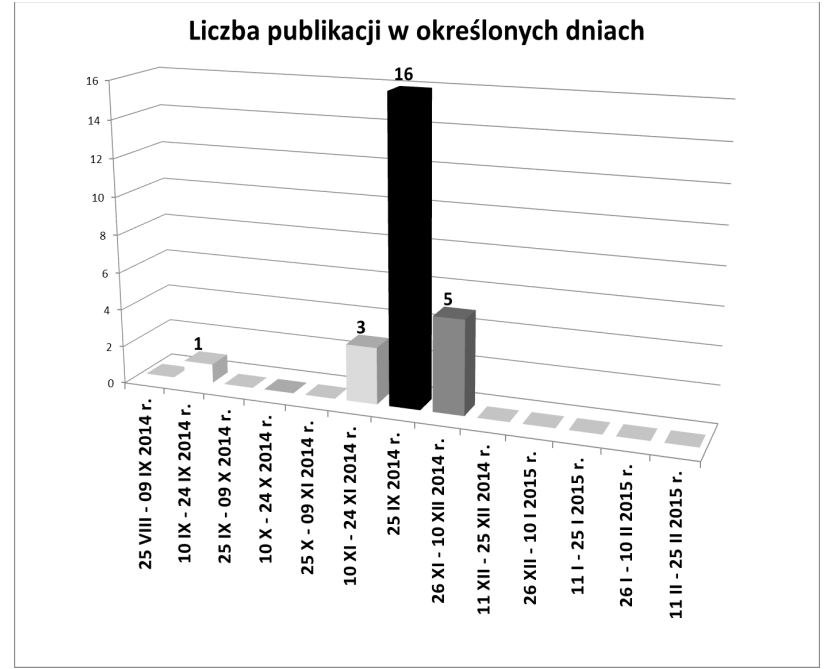

Wyk. 17. Liczba publikacji na temat wizyty papieża Franciszka we Francji w polskich portalach, według terminu publikacji, N=25. Źródło: Newspoint.

24 Zob. [b.a.], Papież złoży 25 listopada wizytę w Parlamencie Europejskim, http://www.wiadomosci.onet.pl/swiat/papiez-zlozy-25-listopada-wizyte-w-parlamencie-europejskim/dmphy (dostęp 9.04.2016 r.).

25 Zob. [b.a.], Watykan wyciąga rękę do Moskwy, _http://www.fakty.interia.pl/religia/news-watykan-wyciaga-reke-do-moskwy,nId,1570201y (dostęp 9.04.2016 r.). 


\section{KOŚCIÓŁ I MEDIA}

\subsubsection{Miejsce publikacji}

Jeśli chodzi o źródła analizowanych danych, najwięcej informacji na temat tej pielgrzymki opublikował portal www.onet.pl (15), co daje mu udział około $60 \%$ w rynku informacji internetowych na ten temat. Najmniej informacji opublikowały www.wp.pl i www.gazeta.pl (2) i www.fakt.pl i www.o2.pl (0), które wydarzeniem nie były zainteresowane.

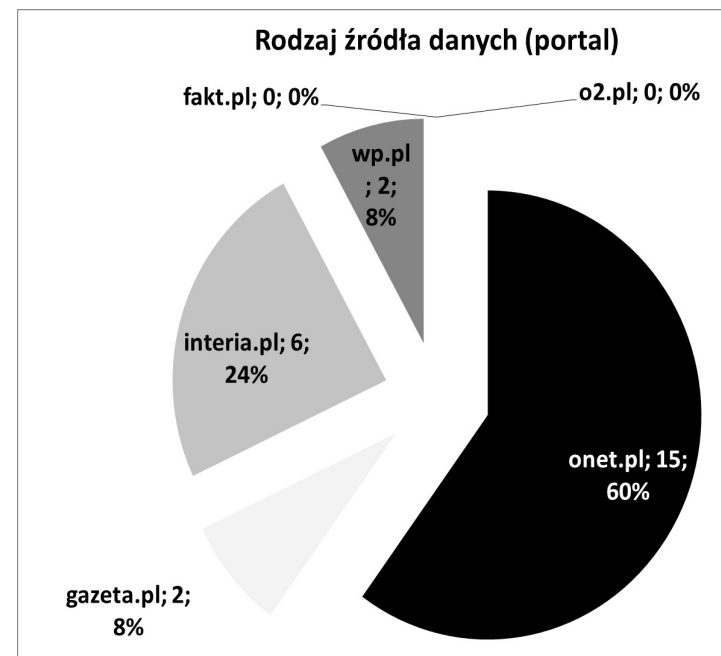

Wyk. 18. Liczba publikacji na temat wizyty papieża Franciszka we Francji w polskich portalach, według miejsca publikacji, N=25. Źródło: Newspoint.

\subsubsection{Rodzaj publikacji}

Następnym etapem prowadzonych badań było określenie sposobu komunikowania o tej pielgrzymce. Z przeprowadzonych badań wynika, że $9 / 10$ opublikowanych informacji było pozytywnych (18) lub neutralnych (5).

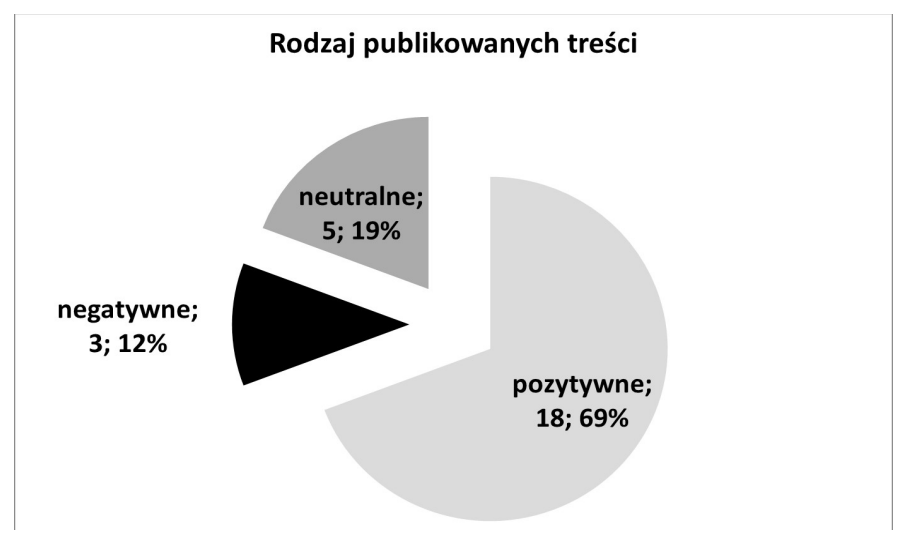

Wyk. 19. Liczba publikacji na temat wizyty papieża Franciszka we Francji w polskich portalach, według rodzaju publikacji, N=25. Źródło: Newspoint. 


\subsubsection{Rodzaj i miejsc publikacji}

Udział informacji negatywnych i neutralnych był wśród poddawanych analizie portali porównywalny. Wyjątkiem wydaje się być www.interia.pl, w której proporcje były nieco proporcje były inne, gdyż więcej było informacji nacechowanych pejoratywnie. Warto zauwa$\dot{z} y c ́$, że na czterech portal informacje nie były publikowane lub było ich tak mało, że nie można było dokonać rzetelnych badań.

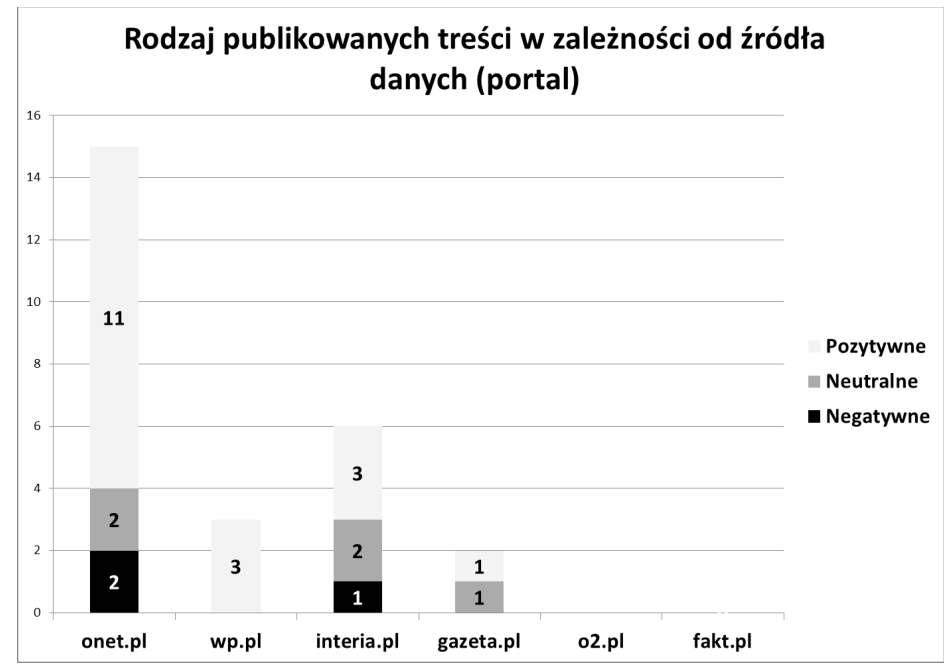

Wyk. 20. Liczba publikacji na temat wizyty papieża Franciszka we Francji w polskich portalach, według miejsca i rodzaju publikacji, N=25. Źródło: Newspoint.

Większości badanych portali internetowych posługuje się informacjami zaczerpniętymi z PAP, KAI i RAI. Pojawily się także komentarze polskich polityków. Publikacje o wydźwięku negatywnym pojawiały się przed samą wizytą papieską i akcentowały oburzenie pobytem papieża w PE wśród działaczek feministycznych oraz w środowiskach LGBT, ujawniające się w organizacji performance'ów, w tym pozorowanego uprowadzenia księdza ${ }^{26}$. Opublikowane zostało także kontrowersyjne podsumowanie przemówienia papieskiego przez Janusza Korwin-Mikkego ${ }^{27}$. Materiałów pogłębiających wydźwięk i treści wypowiadane przez papieża w zasadzie nie publikowano. W dniu wizyty apostolskiej publikowano jedynie informacje agencyjne z pojedynczymi komentarzami publicystycznymi ${ }^{28}$.

26 Zob. [b.a.], Feministki Femenu porwały księdza. Francja w szoku, http://www.fakty.interia.pl/swiat/news-feministki-femenu-porwaly-ksiedza-francja-wszoku,nId,1563417 (dostęp 11.04.2016 r.); [b.a.], Działaczka Femenu topless protestuje w Strasburgu, http://www.wiadomosci.onet.pl/swiat/dzialaczka-femenu-topless-protestuje-w-strasburgu/g738h (dostęp 11.04.2016 r.).

27 [b.a.], Janusz Korwin-Mikke zarzuca papieżowi Franciszkowi sojusz z lewicą, http://www.wiadomosci.onet.pl/swiat/janusz-korwin-mikke-zarzuca-papiezowi-franciszkowi-sojusz-z-lewica/9mxn1 (dostęp 11.04.2016 r.). 


\subsection{8-30 listopada 2014 r. - Turcja}

Szósta podróż apostolska papieża Franciszka, do Turcji, odbyła się w dniach od 28 do 30 listopada $2014 \mathrm{r}$. Była to ostatnia pielgrzymka w analizowanym roku. Obejmowała dwa miasta: Ankarę i Stambuł. 12 września 2014 r. podróż została potwierdzona przez służby prasowe Stolicy Apostolskiej, choć władze Turcji długo oficjalnie nie potwierdzały zaproszenia dla papieża. Sama społeczność katolików tureckich nie ma osobowości prawnej. W toku wizyty nie odbyła się ani jedna Msza św. w miejscu publicznym. Katolicy mogli brać udział tylko we Mszy św. w stambulskiej katedrze św. Ducha, która mieści ok. 500 osób. W trakcie wizyty papież Franciszek podarował w Stambule patriarsze Bartłomiejowi I kopię IX-wiecznej mozaiki Jezusa, której oryginał znajduje się w Bazylice św. Piotra na Watykanie. Ostatniego dnia papież spotkał się z młodzieżą ze stambulskiego ośrodka salezjańskiego, wśród której byli także uchodźcy z Syrii i Iraku. Franciszek odwiedził w szpitalu Mesroba II Mutafiana, ormiańskiego patriarchę Konstantynopola.

\subsection{Termin i częstotliwość publikacji}

W portalach poddawanych analizie opublikowano zaledwie 27 tekstów na jej temat. Pierwszym była informacja z 11 września 2014 r. na portalu www.onet.pl. Była to zapowiedź prasowa planowanej wizycie papieża Franciszka w Turcji i jej potwierdzenie u rzecznika Watykanu. Tej wiadomości nie potwierdzały władze z Ankary ${ }^{29}$. Ostatnia publikacja ukazała się, 6 grudnia, także w serwisie www.onet.pl i była przesłaniem papieża Franciszka do chrześcijańskich uchodźców z Iraku, gdzie komentował i cytował swoje nauczanie z Ankary ${ }^{30}$. Warto zauważyć, że informacje na temat pielgrzymki do Turcji były publikowane już dwa miesiące wcześniej. Na dość dużą liczbę informacji przez wyjazdem papieża do Turcji miała wpływ grupa doniesień o planowanych zamachach na biskupa Rzymu ${ }^{31}$. Relacje związane z pielgrzymką ukazywały w okresie jej trwania. Były to najczęściej depesze agencyjne. Najwięcej informacji opublikowano w okresie dnia przed papieską podróżą apostolską (3), a także w jej trakcie (13) i bezpośrednio po niej (5).

28

Zob. [b.a.], Papież Franciszek wstrząsnął starą Europą, http://www.fakty.interia.pl/religia/news-papiez-franciszek-wstrzasnal-stara-europa,nId,1564488 (dostęp 11.04.2016 r.); [b.a.], Katecheza strasburska, http://www.tygodnik.onet.pl/wiara/katecheza-strasburska/y3kvg (dostęp 11.04.2016 r.). 


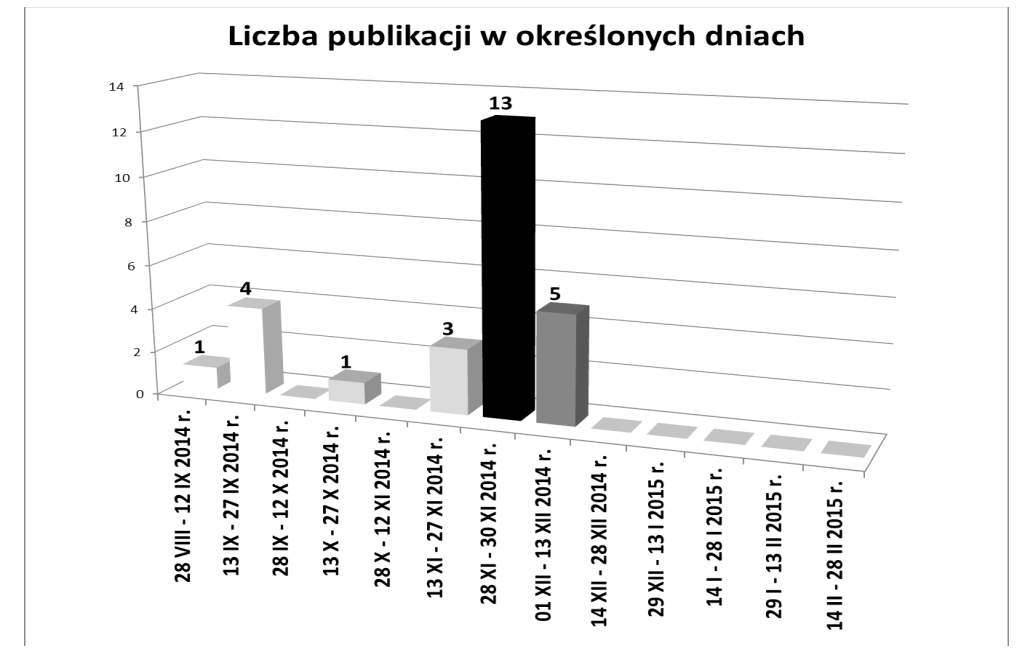

Wyk. 21. Liczba publikacji na temat wizyty papieża Franciszka w Turcji w polskich portalach, według terminu publikacji, N=27. Źródło: Newspoint.

\subsubsection{Miejsce publikacji}

Najwięcej informacji na temat pielgrzymki do Turcji opublikował portal www.onet.pl (12), co daje mu udział około $44 \%$ w rynku informacji internetowych na ten temat. W ogóle informacji nie opublikowały www.fakt.pl i www.o2.pl (0), które nie były zainteresowane wydarzeniem.

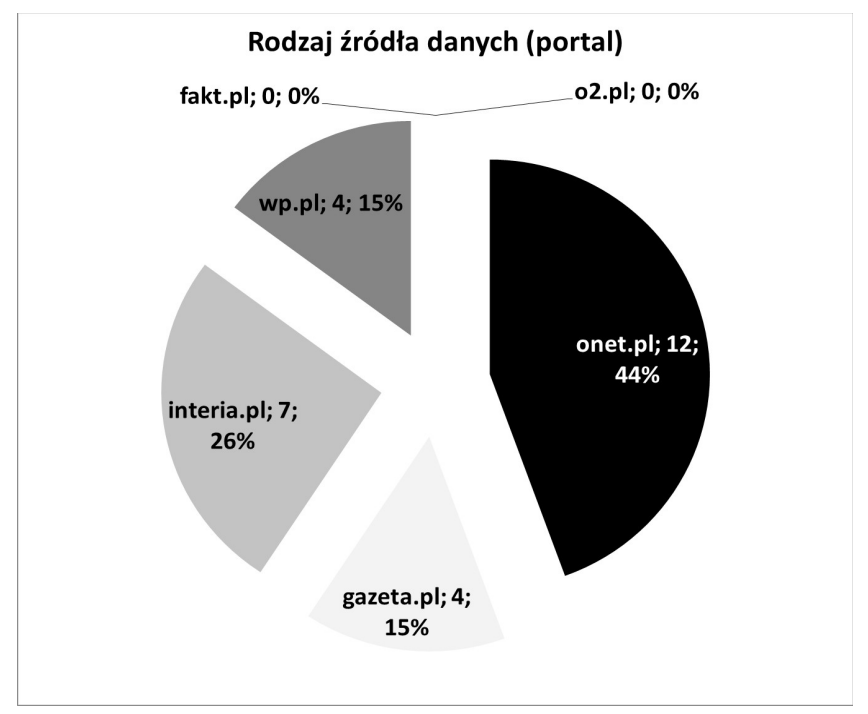

Wyk. 22. Liczba publikacji na temat wizyty papieża Franciszka w Turcji w polskich portalach, według miejsca publikacji, N=27. Źródło: Newspoint. 


\section{KOŚCIÓŁ I MEDIA}

\subsubsection{Rodzaj publikacji}

Następnym etapem prowadzonych badań było określenie sposobu komunikowania o tej pielgrzymce apostolskiej papieża Franciszka. Z przeprowadzonych badań wynika, że 7/8 opublikowanych informacji było pozytywnych (7) lub neutralnych (16). Zauważalny jest wzrost liczby informacji neutralnych, ze względu na przedruki depesz agencyjnych, a brak obecności w nich szerszych komentarzy.

Rodzaj publikowanych treści

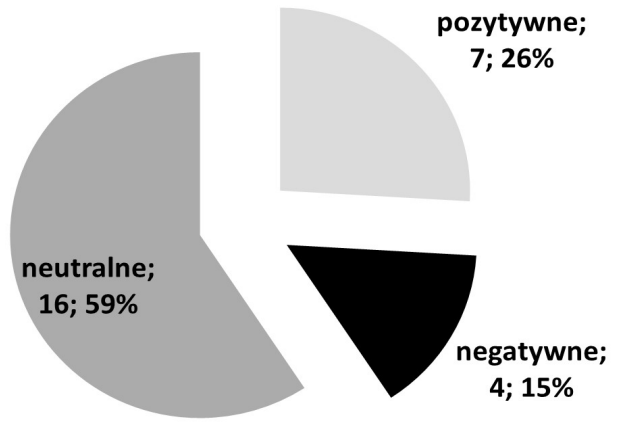

Wyk.23. Liczba publikacji na temat wizyty papieża Franciszka w Turcji w polskich portalach, według rodzaju publikacji, N=27. Źródło: Newspoint.

\subsubsection{Rodzaj i miejsce publikacji}

Udział negatywnych i neutralnych informacji był porównywalny wśród portali poddawanych analizie. Wyjątkiem wydaje się być www.wp.pl, gdzie udział negatywnych informacji w ich ogólnej liczbie wynosił $25 \%$.

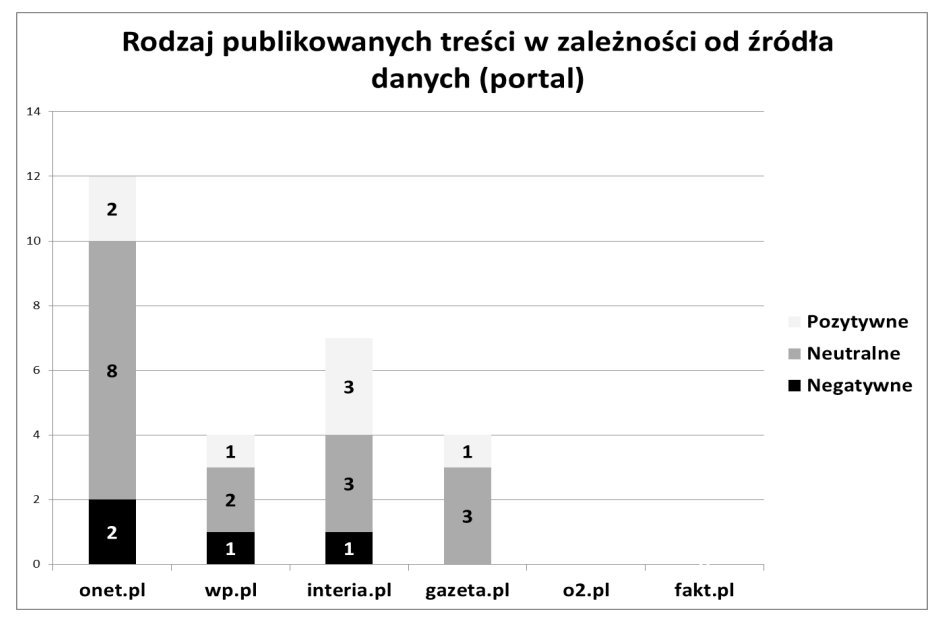

Wyk. 21. Liczba publikacji na temat wizyty papieża Franciszka w Turcji w polskich portalach, według miejsca i rodzaju publikacji, N=27.Źródło: Newspoint. 
Większość badanych portali internetowych posługuje się depeszami zaczerpniętymi z PAP, KAI i RAI. Przed papieską wizytą pojawiały się publikacje o wydźwięku negatywnym, które akcentowały zagrożenie życia papieża związane z obecnością w Turcji, kraju o większości muzułmańskiej, ze strony dżihadystów oraz terrorystów z tzw. Państwa Islamskiego ${ }^{32}$. Materiałów pogłębiających wydźwięk i treści wystąpień papieża nie publikowano. W dzień wizyty apostolskiej publikowano jedynie informacje agencyjne z pojedynczymi komentarzami publicystycznymi ${ }^{33}$.

\section{Analiza teologiczna publikowanych tekstów}

Bez wątpienia główną częścią informacji dotyczących pielgrzymek papieskich były newsy agencyjne (depesze), najczęściej publikowane za Katolicką Agencją Informacyjną (KAI), Polską Agencją Prasową (PAP) i Radiową Agencją Informacyjną (RAI). Było ich 168 na 276 , co stanowi $60,9 \%$ ogólnych informacji. To treści publikowane bez podania autora i duplikowane. Ta sama wiadomość pojawiała się więc w kilku portalach internetowych. Wiadomości takie mają charakter informacyjny i nie zawierają w zasadzie żadnych treści misjologicznych czy teologicznych. Agencje świeckie skupiają się niemal wyłączeni na informacjach budzących emocje, a więc takich, które budzą największe zainteresowanie użytkowników portali.

Pierwsza papieska pielgrzymka do Brazylia (22-29 lipca 2013 r.), zaplanowana była jeszcze przez papieża Benedykta XVI i związana była ze Światowymi Dniami Młodzieży. Podróż ta relacjonowana była najszerzej, bo uzyskała 99 publikacji w analizowanych portalach. Przed pielgrzymką dominowały newsy agencyjne dotyczące przygotowań infrastruktury, jej kosztów, zabezpieczenia, liczby pielgrzymów ${ }^{34}$. W trakcie pielgrzymki i po niej oprócz tego rodzaju newsów pojawiały się komentarze dotyczące wydarzeń i nauczania papieskiego. Dziennikarze zwracali uwagę na „latynoamerykańską opcję na ubogich ${ }^{35}$, biblijne źródła wiary, głoszenie Ewangelii, zwłaszcza ubogim,

32 Tamże.

Zob. [b.a.], Papież: Wierzący powinni przeciwstawić się fanatyzmowi. Erdogan: Niesprawiedliwość popycha ludzi ku Al-Kaidzie,

http://www.wiadomosci.gazeta.pl/wiadomosci/1,114871,17047041,Papiez__Wierzacy_powinni_przeciwstawic_sie_fanatyzmowi_html (dostęp 12.04.2016 r.); [b.a.], Papież Franciszek w Stambule, http://www.fakty.interia.pl/galerie/swiat/zdjecie,iId,1605249,iAId,129974 (dostęp 12.04.2016 r.); [b.a.], Papież Franciszek w Blękitnym Meczecie i w Hagia Sofia w Stambule, http://www.wiadomosci.wp.pl/kat,59154,title,Papiez-Franciszek-w-Blekitnym-Meczecie-i-w-Hagia-Sofia-w-Stambule,wid,17067709,wiadomosc.html (dostęp 12.04.2016 r.).

Zob. [b.a.], Gaz łzawiący podczas protestu przeciwko wizycie papieża, http://www.fakty.interia.pl/raport-nowy-papiez/aktualnosci/news-gaz-lzawiacy-podczas-protestu-przeciwko-wizyciepapieza,nId,998158 (dostęp 4.05.2016 r.); [b.a.], Papież o Światowym Dniu Młodzieży w Rio de Janeiro, http://www.wiadomosci.onet.pl/swiat/papiez-o-swiatowym-dniu-mlodziezy-w-rio-de-janeiro/2fh0p (dostęp 4.05.2016 r.); [b.a.], Copacabana czeka na młodych z całego świata, http://www.wiadomosci.wp.pl/martykul.html?wid=15839000\&kat=1356 (dostęp 4.05.2016 r.). 
i krzewienie kultury spotkania, będącej przeciwieństwem „kultury odrzucenia”, powszechne powołanie do bycia misjonarzami, którzy czerpią radość z osobowego spotkania z Chrystusem, a także zasady homiletyczne (homilia ma być krótka, wygłoszona komunikatywnym językiem) $)^{36}$.

Druga papieska podróż apostolska odbyła się od 24 do 26 maja 2014 r., a jej celem były Jordania, Palestyna i Izrael - Ziemia Święta. Na jej temat w analizowanych portalach opublikowano 60 tekstów, z których znaczna większość była newsami agencyjnymi, zapowiedziami papieskiej podróży ${ }^{37}$. Teksty z opracowaniami pielgrzymki pojawiły się pod koniec jej trwania i tydzień później. Dziennikarze zwrócili uwagę na dialog międzyreligijny oraz wolność religijną i pomoc uchodźcom w kontekście realizowania wskazań Ewangelii i życia nią przez chrześcijan. Ponadto papież Franciszek ukazywał biblijne podstawy pokoju. Innym tematem, który zauważyli publicyści, było wzajemne przebaczenie, a także działania w celu promocji człowieka ${ }^{38}$.

rządku miłości (zasada solidarności) w zainteresowaniu Kościoła. Powiązana również w wielu aspektach z zasadą sprawiedliwości. Została wprowadzona do społecznej nauki Kościoła przez Jana Pawła II w „Sollicitudo rei socialis”. Wprowadzając tę kategorię, papież chciał przeciwstawić się skrajnym nurtom teologii wyzwolenia w Ameryce Łacińskiej, odwołującej się do marksistowskiej ideologii walki klas. Wprawdzie podzielał on troskę o sytuację ludzi najuboższych w świecie, ale odrzuca rozwiązanie tego problemu na drodze rewolucji. Zob. A. Pietrzak, Opcja na rzecz ubogich znakiem wiarygodności Kościoła, Pieniężno 2002.

Zob. [b.a.], Papież Franciszek na Światowych Dniach Młodzieży w Rio de Janeiro, http://www.wiadomosci.wp.pl/kat,59154,title,Papiez-Franciszek-z-wizyta-w-Rio-de-Janeiro,wid,15834815,wiadomosc.html (dostęp 4.05.2016 r.); [b.a.], Brazylia: papież wstrzymał cały konwój, aby wycałować dzieci, http://www.wiadomosci.onet.pl/swiat/brazylia-papiez-wstrzymal-caly-konwoj-aby-wycalowacdzieci/17srj (dostęp 4.05.2016 r.); [b.a.], Papież Franciszek u mieszkańców faweli Manguinhos w Rio, 25 lipiec 2013 r., w: http://www.wiadomosci.wp.pl/kat,1356,title,Papiez-Franciszek-u-mieszkancow-faweliManguinhos-w-Rio,wid,15845656,martykul.html (dostęp 4.05.2016 r.); [b.a.], Papież wyspowiadał pięcioro młodych i spotkał się z więźniami, http://www.wiadomosci.onet.pl/swiat/papiez-wyspowiadal-piecioro-mlodych-i-spotkal-sie-z-wiezniami/64btrl (dostęp 4.05.2016 r.); [b.a.], Papież krytykuje Kościół za to, że traci wiernych, http://www.wiadomosci.gazeta.pl/wiadomosci/1,114871,14348375,Papiez_krytykuje_brazylijski_Kosciol_za_to_zze_traci.html (dostęp 4.05.2016 r.); [b.a.], Papież Franciszek zakończył wizytę w Brazylii, 29 lipiec 2016 r., http://www.wiadomosci.wp.pl/kat,1329,title,Papiez-Franciszekzakonczyl-wizyte-w-Brazylii,wid,15850808,wiadomosc.html (dostęp 4.05.2016 r.); [b.a.], Papież Franciszek m.in. o gejach i wyświęcaniu kobiet, 29 lipiec 2013 r., http://www.wiadomosci.onet.pl/swiat/papiez-franciszek-m-in-o-gejach-i-wyswiecaniu-kobiet/1tgbg (dostęp 4.05.2016 r.); [b.a.], Papież Franciszek w Brazylii wprawił ochronę w zaklopotanie, http://www.wiadomosci.onet.pl/swiat/papiez-franciszekwprawil-ochrone-w-zaklopotanie/3qls5, (dostęp 4.05.2016 r.).

Zob. [b.a.], Izrael: Akty wandalizmu przed wizytą papieża,

http://www.wiadomosci.wp.pl/kat,1356,wid,16589820,martykul.html (dostęp 4.05.2016 r.); [b.a.], Watykan: To jak spacer po polu minowym, http://www.fakty.interia.pl/raport-nowypapiez/aktualnosci/news-watykan-to-jak-spacer-po-polu-minowym,nId,1427912 (dostęp 4.05.2016 r.); [b.a.], Podróż papieża Franciszka do Ziemi Świętej, http://www.fakty.interia.pl/raport-nowy-papiez/aktualnosci/news-podroz-papieza-franciszka-do-ziemi-swietej,nId,1431492 (dostęp 4.05.2016 r.).

Zob. [b.a.], Papież Franciszek przybył do Betlejem. "Każde jego słowo będzie tu bacznie śledzone", http://www.wiadomosci.gazeta.pl/wiadomosci/1,114871,16028852,Papiez_Franciszek_przybyl_do_Betlejem___Kazde_jego.html (dostęp 4.05.2016 r.); [b.a.], Papież zaprosił do Watykanu przywódców Palestyńczyków i Izraela, http://www.fakty.interia.pl/raport-nowy-papiez/aktualnosci/news-papiez-zapro- 
Korea Południowa to cel kolejnej apostolskiej wizyty papieża Franciszka, która odbyła się w dniach od 14 do 18 sierpnia $2014 \mathrm{r}$. W analizowanych portalach ukazało się 49 publikacji na temat tej pielgrzymki. W zasadzie wszystkie zamieszczono w ciągu tygodnia przed, tygodnia po i w trakcie pielgrzymki. Zdecydowana większość z nich była powielanymi informacjami agencyjnymi. Według dziennikarzy poprzez wizytę w Korei Południowej papież wyraźnie dał do zrozumienia, że Azja powinna stanowić priorytet jego pontyfikatu. Ponadto zwrócił uwagę świata zachodniego na specyfikę Kościoła koreańskiego założonego przez świeckich misjonarzy. Innym tematem było zauważanie dojrzewania Kościoła miejscowego, który z Kościoła przyjmującego misjonarzy stał się Kościołem ich wysyłającym. Papież podkreślał powszechne powołanie do bycia misjonarzem, a także konieczność wprowadzania jedności i pokoju ${ }^{39}$.

Czwartą, jedenastogodzinną pielgrzymkę, odbył papież Franciszek do europejskiej Albanii (21 września 2014 r.). Jej celem była beatyfikacja męczenników, którzy zostali zamordowani w czasach komunizmu w tym kraju. Spośród niewielu, bo 16 tekstów opublikowanych w analizowanych portalach, część była powielonymi newsami z agencji prasowych. Informacje o pielgrzymce do Albanii ukazywały się przez dziewięć dni (1625 września 2014 r.). Pozostałe akcentowały konieczność prowadzenia dialogu międzyreligijnego, umiejętność życia w społeczeństwie multikulturowym i wieloreligijnym. Podkreślono świadectwo życia chrześcijan jako tych, którzy wprowadzają pokój. Niepokój, wzajemne prześladowania są dla papieża działaniem szatana ${ }^{40}$.

sil-do-watykanu-przywodcow-palestynczykow-i-izra,nId,1431747 (dostęp 4.05.2016 r.); Z. Radzik, To jest siła Kościoła powszechnego, w którym stoisz tak ramię w ramię mimo różnic, http://www.tygodnik.onet.pl/wiara/zuzanna-radzik-z-ziemi-swietej-to-jest-sila-kosciola-powszechnego-w-ktorym-stoisztak/yxwwe (dostęp 4.05.2016 r.); [b.a.], Papież: wyrzec się gestów, zaprzeczających deklarowanej woli pokoju, http://www.wiadomosci.onet.pl/swiat/papiez-wyrzec-sie-gestow-zaprzeczajacych-deklarowanej-woli-pokoju/j1mj4 (dostęp 4.05.2016 r.); M. Zając, Dwie ściany płaczu,

http://www.tygodnik.onet.pl/wiara/dwie-sciany-placzu/4b9ms (dostęp 4.05.2016 r.); [b.a.], Plan dla Ziemi Świętej, http://www.fakty.interia.pl/religia/news-plan-dla-ziemi-swietej,nId,14374431, (dostęp 4.05.2016 r.).

Zob. [b.a.], Papież z chmur pozdrowi Chińczyków, http://www.fakty.interia.pl/raport-nowy-papiez/aktualnosci/news-papiez-z-chmur-pozdrowi-chinczykow,nId,1484081 (dostęp 4.05.2016 r.); [b.a.], Niezwykłość wspólnoty wiernych w Korei Południowej, http://www.fakty.interia.pl/religia/news-niezwykloscwspolnoty-wiernych-w-korei-poludniowej,nId,1484845 (dostęp 4.05.2016 r.); [b.a.], Papież: Poczucie beznadziei narasta niczym rak w społeczeństwach, http://www.fakty.interia.pl/raport-nowy-papiez/aktualnosci/news-papiez-poczucie-beznadziei-narasta-niczym-rak-w-spoleczenstw,nId,1485844 (dostęp 4.05.2016 r.); [b.a.], Korea Płd.: Papież wyszedł do głodującego ojca, http://www.fakty.interia.pl/raport-nowy-papiez/aktualnosci/news-korea-pld-papiez-wyszedl-do-glodujacego-ojca,nId,1486059 (dostęp 4.05.2016 r.); [b.a.], Apel papieża do młodzieży. O skromniejszy i misyjny Kościół, http://www.fakty.interia.pl/raport-nowy-papiez/aktualnosci/news-apel-papieza-do-mlodziezy-o-skromniejszy-i-misyjny-kosciol,nId,1486338, (dostęp 4.05.2016 r.); [b.a.], Papież Franciszek ochrzcił ojca jednej z ofiar zatonięcia promu, http://www.wiadomosci.onet.pl/swiat/papiez-franciszek-ochrzcil-ojca-jednej-z-ofiar-zatonieciapromu/16dpm (dostęp 4.05.2016 r.); [b.a.], Papież wzywa Koreańczyków z Północy i Południa do wzajemnego przebaczenia, http://www.fakty.interia.pl/religia/news-papiez-wzywa-koreanczykow-z-polnocy-i-poludnia-do-wzajemnego,nId,1486387 (dostęp 4.05.2016 r.). 
Czterogodzinna podróż apostolska papieża Franciszka do Strasburga odbyła się 25 listopada 2014 r. Głównym celem była wizyta w Parlamencie Europejskim i w Radzie Europejskiej w Strasburgu, gdzie wygłosił przemówienia. W analizowanych portalach zamieszczono 24 teksty na temat podróży i wystąpień. Większość z nich (21) została opublikowana w ciągu trzech dni (24-26 listopada). W dużej mierze były to publikacje autorskie. Poruszano w nich temat promocji ludzkiej w Europie, wykluczenia najsłabszych i prymatu materializmu praktycznego nad duchem. Według publicystów papież zwrócił uwagę na konieczność dialogu i wprowadzenia prawdziwego pokoju, który pochodzi od Boga $^{41}$.

Ostatnią pielgrzymką w analizowanym okresie była wizyta apostolska papieża Franciszka w Turcji (28-30 listopada 2014 r.). Liczba informacji agencyjnych i komentarzy autorskich na jej temat była zrównoważona i zamknęła się w liczbie 27. Prawie wszystkie relacje były opublikowane $w$ trakcie jej trwania, a także trzy dni przed i trzy dni po niej. Dziennikarze akcentowali apel o równe traktowanie wyznawców różnych religii, o wysiłek na rzecz walki z terroryzmem. Wskazywał chrześcijanom i ludziom dobrej woli konieczność zajęcia się ludźmi wykluczonymi, ubogimi, na peryferiach świata (latynoska opcja na rzecz ubogich), a szczególnie uchodźcami. Mówił także o problemie braku jedności chrześcijan ${ }^{42}$.

40 Zob. [b.a.], Iracki ambasador w Watykanie: Państwo Islamskie chce zabić papieża, http://www.wiadomosci.wp.pl/kat,1329,wid,16888735,martykul.html (dostęp 7.05.2016 r.); M. Szewczyk, Kraj bunkrów i świątyń, http://www.fakty.interia.pl/religia/news-kraj-bunkrow-i-swiatyn,nId,1500647 (dostęp 7.05.2016 r.); M. Żyła, W Albanii trwają ostatnie przygotowania do wizyty Franciszka, http://www.tygodnik.onet.pl/wiara/w-albanii-trwaja-ostatnie-przygotowania-do-wizyty-franciszka-korespondencja-marcina/w7x5j (dostęp 7.05.2016 r.); [b.a.], Papież Franciszek: Albania to kraj męczenników,

http://www.wiadomosci.onet.pl/swiat/papiez-franciszek-albania-to-kraj-meczennikow/p8htn (dostęp 7.05.2016 r.); [b.a.], Papież Franciszek powrócił z Albanii do Rzymu, http://www.wiadomosci.wp.pl/kat,1356,wid,16900243,martykul.html (dostęp 7.05.2016 r.); [b.a.], Papieskie przesłanie nadziei, http://www.fakty.interia.pl/raport-nowy-papiez/aktualnosci/news-papieskie-przeslanie-nadziei,nId,1505153 (dostęp 7.05.2016 r.).

41 Zob. [b.a.], Papież Franciszek w PE: Europa to babcia, już bezpłodna i nietętniąca życiem, http://www.wiadomosci.gazeta.pl/wiadomosci/1,114871,17024916,Papiez_Franciszek_w_PE_Europa_to_babcia_juz_bezplodna.html (dostęp 4.05.2016 r.); [b.a.], Europosłowie z uznaniem o słowach papieża. A Korwin-Mikke: To sojusz lewego tronu z lewym ołtarzem,

http://www.wiadomosci.gazeta.pl/wiadomosci/1,114871,17026106,Europoslowie_z_uznaniem_o_slowach_papieza_A_Korwin_Mikke_.html (dostęp 7.05.2016 r.); [b.a.], Papież przybył do Strasburga $i$ wygłosił przemówienie w PE, http://www.wiadomosci.wp.pl/kat,89914,wid,17056466,martykul.html (dostęp 7.05.2016 r.); [b.a.], Katecheza strasburska, http://www.tygodnik.onet.pl/wiara/katecheza-strasburska/y3kvg, [dostęp 07 V 2016 r.]; G. Makara, Szkoła Ateńska Papieża Franciszka, http://www.tygodnik.onet.pl/wiara/szkola-atenska-papieza-franciszka/ep31r (dostęp 7.05.2016 r.).

42 Zob. [b.a.], Teściowe modlą się o niebo, http://www.tygodnik.onet.pl/wiara/tesciowe-modla-sie-oniebo/jt83n (dostęp 8.05.2016 r.); [b.a.], Papież: Wierzący powinni przeciwstawić się fanatyzmowi. Erdogan: Niesprawiedliwość popycha ludzi ku Al-Kaidzie,

http://www.wiadomosci.gazeta.pl/wiadomosci/1,114871,17047041,Papiez__Wierzacy_powinni_przeciwstawic_sie_fanatyzmowi_html (dostęp 8.05.2016 r.); [b.a.], Papież Franciszek w Stambule, http://www.fakty.interia.pl/galerie/swiat/zdjecie,iId,1605249,iAId,129974 (dostęp 8.05.2016 r.); [b.a.], Papież odprawił mszę w katedrze w Stambule, http://www.wiadomosci.onet.pl/swiat/papiez-odprawil- 


\section{Wnioski pastoralne}

Bez wątpienia obecność Kościoła i jego instytucji w przestrzeni wirtualnej jest konieczna, a nawet niezbędna, aby prowadzić ewangelizację za pomocą wszelkich dostępnych środków. Internet, jako przestrzeń wielopłaszczyznowa, może stać się zarówno miejscem wymiany myśli, ewangelizacji, jak i narzędziem głoszenia ewangelii. J. Kloch wysuwa postulat wykorzystania Internetu jako narzędzia obecności Kościoła w tej przestrzeni. Uważa, że Kościól, jego wspólnoty partykularne i instytucje, powinny wykorzystywać to narzędzie do głoszenia Dobrej Nowiny (ewangelizacja, katechizacja, informacja), uświęcania (Pismo św., modlitwa, rekolekcje, pielgrzymki), szerzenia dobroczynności (pomoc socjalna, wolontariat, współpraca, tworzenie społeczności wokół danej inicjatywy) i nauczania (refleksja teologiczna, edukacja wspólnoty eklezjalnej) ${ }^{43}$.

Warto zwrócić uwagę na kwestię uzyskanych danych. Większość informacji publikowanych wanalizowanych serwisach (www.onet.pl; www.wp.pl; www.interia.pl; www.gazeta.pl; www.o2.pl; www.fakt.pl), była publikowana w trakcie trwania papieskiej pielgrzymki, a pozostałe do $10 \mathrm{dni}$ przed i $10 \mathrm{dni}$ po niej, choć w niektórych wypadkach jedynie trzy dni. Informacje dotyczące danej pielgrzymki „żyły” zatem w najbardziej opiniotwórczych portalach kilka dni, a do tego było ich niewiele, bo średnio mniej niż 50 na wizytę apostolską (46). Były wśród nich takie, np. dotyczące Albanii, które obecne były na portalu przez 2-3 dni. Najczęściej publikowane były wiadomości agencyjne duplikowane bez komentarza. Wyjątkiem były tu portale współpracujące ściśle z redakcjami katolickimi. Najściślejszą współpracę nawiązał serwis www.onet.pl, z „Tygodnikiem Powszechnym”. Natomiast serwis www.interia.pl sięgał czasem po teksty z „Przewodnika Katolickiego”. W tych portalach można zauważyć najwięcej omówień teologicznych i szersze przekazywanie nauczania papieskiego. Wydaje się, że to właściwa droga do tego, aby jak najwięcej informacji związanych z życiem Kościoła ukazywało się w mediach internetowych i aby były one rzetelnie przedstawiane. By doprowadzić do ukazywania się takich treści w tych portalach, trzeba udostępniać je redakcjom. Redakcje też powinny mieć zapewnioną ścisłą współpracę z określonym medium katolickim bądź teologiem-dziennikarzem.

Warto, aby instytucje kościelne szczebla centralnego, np. Biuro Prasowe EP czy rzecznik prasowy Nuncjatury Apostolskiej zbudowali zespół ludzi chcący szerzej zadbać o obecność Kościoła w mediach i tworzący teksty przygotowujące czy podsumowujące chociażby papieskie pielgrzymki. Ważne, aby te materiały były komunikatywne dla odbiorcy internetowego i przygotowywane zgodnie z kanonem dziennikarstwa internetowego.

msze-w-katedrze-w-stambule/jrpkb (dostęp 8.05.2016 r.); [b.a.], Papież Franciszek w Błękitnym Meczecie i w Hagia Sofia w Stambule, http://www.wiadomosci.wp.pl/kat,59154,title,Papiez-Franciszek-w-Blekitnym-Meczecie-i-w-Hagia-Sofia-w-Stambule,wid,17067709,wiadomosc.html (dostęp 8.05.2016 r.); [b.a.], Franciszek w Turcji: herbatka i pojednanie, http://www.tygodnik.onet.pl/wiara/franciszek-w-turcji-herbatka-i-pojednanie/7yb6d (dostęp 8.05.2016 r.); [b.a.], Papież w Konstantynopolu: pragnę jedności i pokoju, http://www.fakty.interia.pl/prasa/przewodnik-katolicki/news-papiez-w-konstantynopolu-pragne-jednosci-i-pokoju,nId,1568716 (dostęp 8.05.2016 r.). 
Zgodnie z postulatem J. Klocha możliwa jest szersza obecność Kościoła w internetowych mediach świeckich. Przez współpracę z mediami internetowymi, które są tym zainteresowane, możliwe jest ich szersze wykorzystywanie, szczególnie do ewangelizacji, katechizacji, informowania, proklamowania nauczania eklezjalnego na dany temat czy tworzenia wspólnoty ludzi, którzy chcą współuczestniczyć w jakieś inicjatywie.

Świat i ludzkie przyzwyczajenia szybko się zmieniają. Najpierw wśród środków społecznego przekazu pojawiły się czasopisma, radio, telewizja, a dziś rozpowszechnionym medium, z którego korzysta około $70 \%$ polskiego społeczeństwa, jest Internet $^{44}$. Być może niedługo zdeklasuje telewizję. Młodzi ludzie sporadycznie czytają czasopisma, słuchają radia, najczęściej są ciągle „online”, za pomocą komputerów i urządzeń przenośnych (telefony, tablety itd.). Oprócz mediów internetowych: stron internetowych, mediów społecznościowych (Facebook, Twitter, Google+, Instagram czy Pinterest), aktualnie największą rolę pełnią najpopularniejsze portale publicystyczne. Niektóre z nich osiągają czytelnictwo na poziomie więcej niż 12,5 mln odbiorców miesięcznie, którzy czytają portal nawet kilka razy dziennie (www.onet.). W ich zasobach powinny znajdować się informacje związane z Kościołem, w tym także z pielgrzymkami papieskimi.

Z przeprowadzonych badań wynika, że pielgrzymki papieskie cieszyły się małym bądź średnio małym zainteresowaniem portali. Informacji z pierwszych sześciu pielgrzymek papieskich (22-29 lipca 2013 r. Brazylia; 24-26 maja 2014 r. - Jordania, Palestyna, Izrael; 14-18 sierpnia 2014 r. - Korea Południowa; 21 września 2014 r. - Albania; 25 listopada 2014 r. - Francja; 28-30 listopada 2014 r. - Turcja) opublikowano jedynie 276. Najczęściej były to newsy publikowane za: Katolicką Agencją Informacyjną (KAI), Polską Agencją Prasową (PAP) i Radiową Agencją Informacyjną (RAI). To 168 spośród 276 wiadomości, co stanowi $60,9 \%$ informacji, które często były duplikowane w różnych serwisach. Czas publikacji najczęściej był tożsamy z samą podróżą apostolską. Czasami była ona poprzedzana zapowiedziami bądź podsumowaniami, ale nie publikowano ich $\mathrm{z}$ wyprzedzeniem większym niż 7 dni. Tak zwana żywotność na portalu pielgrzymki papieskiej to średnio 7 dni (przez tyle dni ukazywały się informacje na jej temat, choć na stronie głównej informacje były obecne przez 2-3 godziny), pod warunkiem, że pielgrzymka w ogóle była zauważona przez dany portal.

Wydaje się, że media te powinny zostać zauważone przez centralne instytucje Kościoła i szerzej informowane, a współpraca z redakcjami katolickimi czy teologami pozwoli na publikowanie większej liczby omówień teologicznych papieskiego nauczania w dłuższym czasie. Ważne, aby teologowie, w tym duchowni, byli przygotowywani także do posługiwania się narzędziami niezbędnymi w uprawianiu tego rodzaju dziennikarstwa.

44 Badanie Megapanel PBI/Gemius z października 2015 r.: https://www.gemius.pl/wszystkie-artykuly-aktualnosci/o-ile-wzrosla-liczba-internautow-w-ciagu-dekady.html. W 2015 roku z internetu korzysta $70 \%$. Polaków, czyli 24,82 mln. osób. Pięć lat temu z Internetu korzystał co drugi mieszkaniec naszego kraju (18,21 mln), a w 2005 roku internautami było $27 \%$ społeczeństwa $(9,55 \mathrm{mln})$. 


\section{BIBLIOGRAFIA}

Benedykt XVI, Nowe technologie, nowe relacje. Trzeba rozpowszechniać kulturę szacunku, dialogu i przyjaźni. Orędzie na 43. Światowy Dzień Środków Społecznego Przekazu, 24 stycznia 2009 r.

Franciszek, Komunikacja i Miłosierdzie-owocne spotkanie. Orędzie na 50. Światowy Dzień Środków Społecznego Przekazu, 24 stycznia 2016 r.

Jan Paweł II, Misja Kościoła w erze komputerów. Orędzie na 24. Światowy Dzień Środków Społecznego Przekazu, 24 stycznia 1990 r.

Kloch J., Kościół w Polsce wobec Web 2.0, Kielce 2013.

Pietrzak A., Opcja na rzecz ubogich znakiem wiarygodności Kościoła, Pieniężno 2002 .

www.fakt.pl

www.gazeta.pl

www.interia.pl

www.02.pl

www.onet.pl

www.wirtualnemedia.pl

www.wp.pl

\section{OAUTORZE:}

ks. dr Marcin Wrzos OMI (ur. 1977 r.), prezbiter, misjonarz oblat Maryi Niepokalanej; doktor teologii o specjalności misjologia i t. środków społecznego przekazu UKSW(2013), ukończył studia z nauk politycznych i dziennikarstwa UAM (2008) i polonistyki UJ (2016). Autor artykuł dotyczących misji w środkach społecznego przekazu i wykorzystania środków społecznego przekazu na misjach. Bada internet w kontekście obecności w nim Kościoła. Autor trzech książek naukowych: „Polskie czasopisma misyjne po II wojnie światowej. Studium misjologiczno - prasoznawcze”, „Bibliografia polskich czasopism misyjnych. Lata 1945-2013” oraz „Oblates missionary press in Europe”(redaktor). Kieruje wydawnictwem “Misyjne Drogi”. Kontakt: marcinwrzos@oblaci.pl 